\title{
The essential Gcd10p-Gcd14p nuclear complex is required for 1-methyladenosine modification and maturation of initiator methionyl-tRNA
}

\author{
James Anderson, ${ }^{1}$ Lon Phan, ${ }^{1}$ Rafael Cuesta, ${ }^{3}$ Bradley A. Carlson, ${ }^{2}$ Marie Pak, ${ }^{1}$ Katsura Asano, ${ }^{1}$ \\ Glenn R. Björk, ${ }^{4}$ Mercedes Tamame, ${ }^{3}$ and Alan G. Hinnebusch ${ }^{1,5}$ \\ ${ }^{1}$ Laboratory of Eukaryotic Gene Regulation, National Institute of Child Health and Human Development, Bethesda, \\ Maryland 20892 USA; ${ }^{2}$ Basic Research Laboratory, Division of Basic Sciences, N ational Cancer Institute, Bethesda, \\ Maryland 20892 USA; ${ }^{3}$ Instituto de Microbiología Bioquímica, Consejo Superior de Investigaciones Científicas, Universidad \\ de Salamanca, Salamanca, Spain; ${ }^{4}$ Department of Microbiology, Umeå U niversity, U meå, Sweden
}

Gcd10p and Gcd14p are essential proteins required for the initiation of protein synthesis and translational repression of G CN 4 mRNA. The phenotypes of gcd 10 mutants were suppressed by high-copy-number IMT

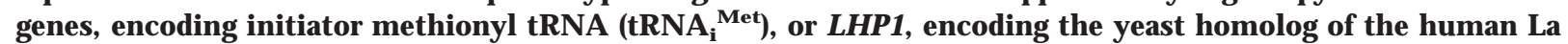
autoantigen. The gcd10-504 mutation led to a reduction in steady-state levels of mature tRNA ${ }_{i}{ }^{\text {Met, }}$, attributable to increased tumover rather than decreesed synthesis of pre-tRNA ${ }_{i}{ }^{\text {Met }}$. Remarkably, the lethality of a G C D 10 deletion was suppressed by high-copy-number IMT4, indicating that its role in expression of mature tRNA $A_{i}{ }^{\text {Met }}$ is the essential function of Gcd10p. A gcd14-2 mutant also showed reduced amounts of mature tRNA $A_{i}$ Met, but in addition, displayed a defect in pretRNA ${ }_{i}{ }^{\text {Met }}$ processing. Gcd10p and Gcd14p were found to be subunits of a protein complex with prominent nuclear localization, suggesting a di rect role in tRNA ${ }_{i}{ }^{\text {Met }}$ maturation. The chromatographic behavior of el ongator and initiator tRNA ${ }^{\text {Met }}$ on a RPC-5 column indicated that both species are altered structurally in gcd10 $\Delta$ cells, and analysis of base modifications revealed that 1-methyladenosine $\left(m^{1} A\right)$ is undetectable in gcd10 $\Delta$ tRNA. Interestingly, gcd10 and gcd14 mutations had no effect on processing or accumulation of elongator tRNA ${ }^{\text {Met }}$, which al so contains $\mathrm{m}^{\mathbf{1}} \mathrm{A}$ at position 58 , suggesting a unique requirement for this base modification in initiator maturation.

[Key Words: Gcd10p-Gcp14p nuclear complex; 1-methyladenosine; tRN A; initiator maturation]

Received August 2, 1998; revised version accepted October 9, 1998.

A key step in the initiation of protein synthesis in eukaryotic cells involves the binding of the methionyl initiator tRN A ${ }^{\text {Met }}$ (Met-tRNA ${ }_{i}^{\text {Met) }}$ to the 40S ribosomal subunit to form a 435 preinitiation complex. Initiation factor 2 (elF2) del ivers $M$ et-tRN $A_{i}{ }^{M}$ et to the ribosome in a ternary complex with GTP, and the elF2 is released in an inactive binary complex with GDP. Exchange of the GDP bound to elF2 for GTP is catalyzed by the guanine nucl eoti de exchange factor elF2B. Phosphorylation of the $\alpha$ subunit of elF2 (elF2 $\alpha$ ) prevents the recycl ing of el F2 by elF2B, inhibiting the formation of elF2 . GTP . MettRN $A_{i}{ }^{\text {Met }}$ ternary complexes (Hershey 1991; Hinnebusch 1996). In Saccharomyces cerevisiae, elF $2 \alpha$ is phosphorylated by the protein kinase Gcn2p when cells are deprived of an amino acid and this elicits increased

${ }^{5}$ Corresponding author.

E-MAIL ahinnebusch@nih.gov; FAX (301) 496-6828. translation of a specific mRN A encoding Gcn4p, a transcriptional activator of amino acid bi osynthetic enzymes (Hinnebusch 1996).

Because translation of GCN4 is coupled inversely to the concentration of ternary complexes (Dever et al. 1995) mutations in subunits of elF2 and elF2B derepress GCN 4 translation in cells lacking Gcn2p (for review, see Hinnebusch 1996). Mutations in GCD 10 al so derepress GCN 4 translation in the absence of elF2 phosphorylation by Gcn2p (Harashima and Hinnebusch 1986). GCD10 is essential and temperature-sensitive mutations in this gene inhi bit general translation initiation at the restrictive temperature. It was found that Gcd10p copurified and coimmunoprecipitated with subunits of translation initiation factor elF3 (Garcia-Barrio et al. 1995). Given their effect on GCN 4 translation, it was proposed that gcd10 mutations reduce the ability of elF3 to stimulate ternary complex binding to 405 ribosomes, 
mimicking the inhibition of ternary complex formation elicited by elF2 phosphorylation. Recently, we purified a yeast el F3 complex from a strain expressing a polyhistidine-tagged form of the PRT1-encoded subunit (Phan et al. 1998) and found that it contains all five S. cerevisiae proteins homologous to subunits of mammalian elF3, but lacks Gcd10p. In addition, Gcd10p was not coimmunoprecipitated with an epitope-tagged version of the TIF34 subunit of yeast elF3 (A sano et al. 1998; Phan et al. 1998). Together, these findings suggested that Gcd10p is not an integral subunit of yeast elF3, and may have a distinct function involved in the formation of ternary complexes or their recruitment to the ribosome.

To identify the in vivo function of Gcd10p, we carried out a genetic analysis by isol ating dosage suppressors of the temperature-sensitive phenotype of gcd10 mutations. A nalysis of these suppressors reveal ed that maturation of initiator tRNA ${ }^{\text {Met }}$ is defective in gcd10 mutants. Our bi ochemical results indicate that Gcd10p resides in a nuclear complex with Gcd14p, another factor involved in GCN 4 translational control (Cuesta et al. 1998), and is required for 1-methyladenosine formation in yeast tRN A. M oreover, GCD 10 was found to be nonessential in cells overexpressing initiator tRNA ${ }^{\text {Met }}$. It appears that the Gcd10p-Gcd14p complex is required specifically at the initiation step of translation because of a strong requirement for 1-methyladenosine at position $58\left(\mathrm{~m}^{1} \mathrm{~A} 58\right)$ in the processing and accumulation of initiator tRN A ${ }^{\mathrm{Met}}$.

\section{Results}

Genes encoding initiator tRNA ${ }^{\text {Met }}$ or a La homolog are dosage suppressors of the growth defects of gcd10 mutants

To identify functional interactions between Gcd10p and components of the translation initiation apparatus, we identified wild-type genes that in high-copy-number enable gcd10 mutants to grow at the nonpermissive temperature. Strains H2457(gcd10-504 gcn2-101) and Hm298 (gcd10-505 gcn2-101) were transformed with a high-copy yeast genomic library, and transformants were selected for growth at $36^{\circ} \mathrm{C}$. Analysis of plasmids recovered from the ts ${ }^{+}$transformants (described in $M$ aterials and $M$ ethods) led to the identification of five dosage suppressors, of which four are the genes encoding initiator tRNA ${ }^{\text {Met }}$, IMT1, IMT2, IMT3, and IMT4 (Cigan and Donahue 1986; Byström and Fink 1989). The remaining suppressor gene was identified as LHP1, encoding a homolog of the human La protein (Yoo and Wolin 1994) previously implicated in processing of tRN As in yeast (Yoo and Wolin 1997) (Fig. 1A). All five genes were found to suppress the effects of gcd10 mutations on GCN4 translation in the following way. Because increased Gcn $4 p$ synthesis is required to derepress the histidine biosynthetic enzyme inhibited by 3-AT (His3p), gcn2 mutants are sensitive to 3-AT. gcd10 mutations lead to derepression of GCN 4 translation in the absence of elF2 phosphorylation by $\mathrm{Gcn} 2 \mathrm{p}\left(\mathrm{Gcd}^{-}\right.$phenotype), conferring resistance to 3-AT (ATr) in a gen2 strain background ( $\mathrm{Ha}$ rashima and Hinnebusch 1986). All of the dosage suppressors overcame the 3-AT ${ }^{r}$ phenotype of gcn2-101 gcd10-504 strain H2457 (data not shown), and thus appear to restore repression of GCN 4 translation.

The presence of IMT1, IMT2, and IMT4 in high copy suppressed the ts ${ }^{-}$phenotypes of the gcd10-504, gcd10505, and gcd10-503 allel es as completely as did low-copy GCD 10; however, high-copy-number IMT3 (hcl MT3) did not suppress fully the ts ${ }^{-}$phenotype of gcd10-505. High copy LHP1 only suppressed partially all three gcd10 alleles (data not shown). Only one additional copy of IMT4 or LHP1 on single-copy pl asmids p2627 and 2628, respectively, did not suppress the phenotypes of gcd10-504 in $\mathrm{H} 2457$ (data not shown), suggesting that overexpression of tRN $A_{i}{ }^{\text {Met }}$ or Lhplp is required for suppression.

We asked whether overexpression of tRN $A_{i}{ }^{\text {Met }}$ or Lhplp would suppress general defects in translation initiation conferred by mutations in known initiation factors. PRT1 encodes the 90-kD subunit of elF3 ( $\mathrm{N}$ aranda et al. 1994) and prt1-1 mutants are impaired for translation initiation at the restrictive temperature both in vivo and in vitro (Feinberg et al. 1982). Unlike the gcd10 mutants, the ts ${ }^{-}$phenotype of a prt1-1 mutant was not suppressed by hclMT4 or hcLHPI (Fig. 1A). Furthermore, neither hclMT4 nor hcLHP1 suppressed the growth defects of sui2-1 or gcd1-501 alleles, encoding defective subunits of elF2 $\alpha$ and elF2B $\gamma$, respectively (data not shown). These findings suggest that Gcd10p promotes translation initiation in a manner specifically involving initiator tRNA ${ }^{\text {Met }}$ metabolism or function.

The abundance of mature initiator tRNA ${ }^{\text {Met }}$ is reduced specifically in a gcd10-504 mutant

To examine whether initiator tRN $\mathrm{A}^{\mathrm{M} \text { et }}$ expression is re duced in gcd10 mutants, we used $\mathrm{N}$ orthern blot analysis to measure the steady-state level s of tRN $A_{i}{ }^{\text {Met }}$ using sequences complementary to the tRN $A_{i}{ }^{\text {Met }}$ coding region as a probe. In addition to mature tRN ${ }_{i}{ }^{\mathrm{Met}}$, this probe hybridized to two larger species that appear to be precursors of tRN $A_{i}{ }^{\text {Met }}$ bearing different $5^{\prime}$ and $3^{\prime}$ terminal extensions encoded by the various IMT genes (see below). The amount of mature tRN $A_{i}{ }^{\text {Met }}$ in the gcd10 mutant was about twofold lower than in the wild type at $26^{\circ} \mathrm{C}$, and only about one-sixth of the wild-type level after 10 hr at $36^{\circ} \mathrm{C}$ (Fig.1B, C; tRN $A_{i}{ }^{\text {Met }}$ ). In contrast, levels of the putative tRN $A_{i}{ }^{\text {Met }}$ precursors were virtually indistinguishable between the mutant and wild-type strains (Fig. $1 B$; pre-tRN $A_{i}{ }^{M e t}$ ), leading to ratios of precursors to mature tRN $A_{i}{ }^{M}$ et three to eightfold higher in the mutant over the course of the experiment (Fig. 1B). These results suggest that transcription of the IMT genes is not impaired in the gcd10 mutant but that a reduction in mature tRN $A_{i}{ }^{\mathrm{Met}}$ abundance occurs at a post-transcriptional step.

Interestingly, the levels of mature tRNA $\mathrm{A}^{\mathrm{His}}$ and tRNA $A_{C G A}$ ser were indistinguishable between the wildtype and gcd 10 strains at the permissive and nonpermissive temperatures (data not shown), whereas we consis- 
A

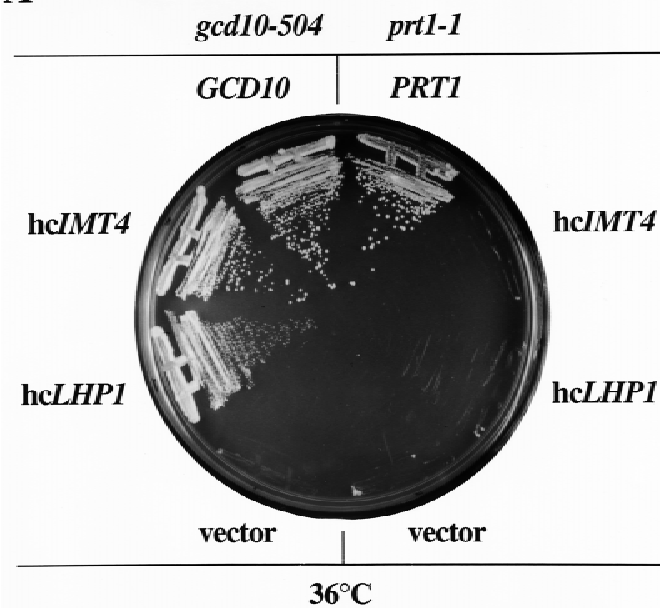

B

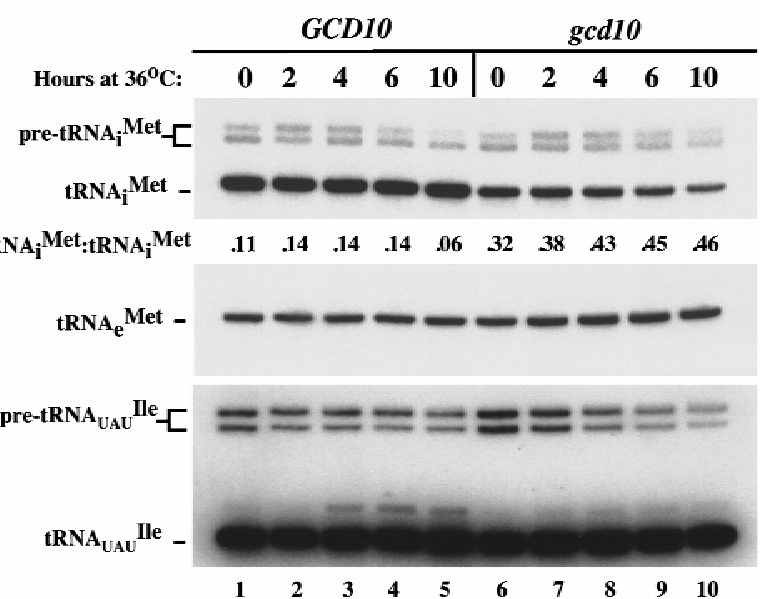

C
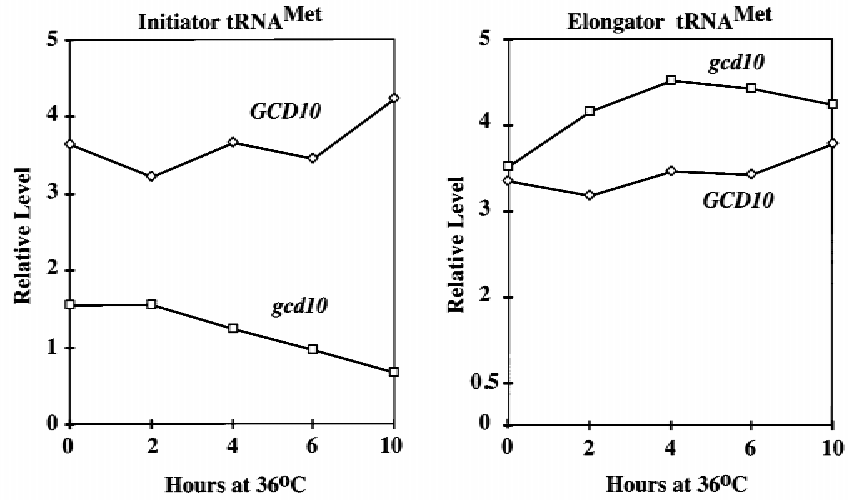

Figure 1. High-copy suppressors of gcd10-504 overcome a defect in accumulation of tRN $\mathrm{A}_{i}{ }^{\mathrm{M} e t}(\mathrm{~A})$ Transformants of strains $\mathrm{H} 2457$ (gcd10-504) and H1676 (prt1-1) containing low-copy plasmids bearing GCD10 (pM G107) (Garcia-Barrio et al. 1995) or PRT1 (p2625), respectively, or high-copy plasmids bearing IMT4 (pC44) (Cigan et al. 1988), LHP1 (p2626), or empty vector Y Ep24 were streaked for single colonies on minimally supplemented SD plates and incubated at $36^{\circ} \mathrm{C}$ for 2 days. (B) N orthern blot analysis of total RN A (5 $\mu$ ) isolated as described (Kohrer and Domdey 1991) from strain H2457 (gcd10-504) bearing GCD 10 on low-copy plasmid pM G 107 (GCD 10 lanes) or empty vector Y Ep24 (gcd10 lanes) grown in supplemented SD at $26^{\circ} \mathrm{C}$ to mid-exponential phase $\left(0 \mathrm{hr}\right.$ at $\left.36^{\circ} \mathrm{C}\right)$ and shifted to $36^{\circ} \mathrm{C}$ for $2,4,6$, or $10 \mathrm{hr}$. The RN As were separated on an $8 \%$ polyacrylamide-bis-acrylamide (19:1), $8.3 \mathrm{~m}$ urea gel by el ectrophoresis and transferred to Hybond- $\mathrm{N}+$ membranes (Amersham). The blot was probed using a radiolabel ed oligonucleotide that hybridized specifically to tRN $A_{i}{ }^{\text {Met }}$, stripped and reprobed with radiolabeled oligonucleotides specific for tRNA ${ }_{e}^{\text {Met }}$ or tRNA $A_{U A U}{ }^{\text {Ile }}$. Direct quantitation of all hybridized probes was conducted by Phosphorlmager analysis using a Storm 860 apparatus (M olecular Dynamics) and ImageQuant software. The positions of pre-tRNA ${ }_{i}{ }^{\text {Met }}$ species, mature tRNA ${ }_{i}{ }^{\text {Met }}, t_{R N A}{ }^{\text {Met }}$, pre-tRNA $A_{U A U}{ }^{\text {Ile }}$, and mature tRNA $_{U A U}$ "le are indicated at left. The relative intensities of the hybridization signals were quantified for mature tRN $A_{i}{ }^{\text {Met }}$ and pre-tRN $A_{i}{ }^{\text {Met }}$, and the ratios of pre-tRN $A_{i}{ }^{\text {et }}$ to mature tRN $A_{i}{ }^{\text {Met }}$ are listed under the appropriate lanes. The species that migrated just above mature tRN $A_{U A U}{ }^{\prime l e}$ and accumulated at high temperature most likely represent spliced precursors still bearing the 3' extension (O'Connor and Peebles 1991). (C) The relative intensities of the hybridization signals in B were quantified by Phosphorlmager analysis of the autoradiograph and plotted against the time of incubation at $36^{\circ} \mathrm{C}$.

tently observed a modest increase in mature elongator tRN A ${ }^{\text {Met }}$ levels in the gcd10 mutant at $36^{\circ} \mathrm{C}$ (Fig. 1B,C; $\operatorname{tRNA} e^{\text {Met }}$ ). The level of pretRN $A_{\text {UAU }}{ }^{\text {Ile }}$ decreased at $36^{\circ} \mathrm{C}$ slightly more in the gcd 10 mutant than it did in the

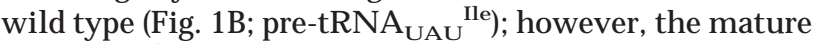
tRNA $\mathrm{UAU}$ "le levels wereidentical in the two strains at all temperatures. These findings suggest that the gcd10 mutation primarily reduces the accumulation of mature $\operatorname{tRNA}{ }_{i}^{\text {Met }}$.
To investigate whether the lowered expression of mature tRN $A_{i}{ }^{M e t}$ in gcd10 cells could be a general response to reduced growth rates, we conducted N orthern blot analysis on the temperature sensitive sui2-1 mutant, and compared the results to those shown in Figure 1B for the gcd10-504 strain (data not shown). The pre-tRN $A_{i}{ }^{\text {Met }}$ level was $\sim 34 \%$ lower in the sui2 mutant versus the SUI2 strain; however, the mature tRN $A_{i}{ }^{\text {Met }}$ level decreased by only $15 \%$ in the sui 2 cells, leading to a small 
reduction in the precursor-to-mature ratio [0.08 (sui2) versus 0.16 (SU I2)]. Thus there was a much greater reduction in mature tR N $A_{i}{ }^{\text {Met }}$ levels in the gcd10 mutant (a factor of 6 , Fig. 1B) versus the sui 2 mutant (15\%), although pretRN $A_{i}{ }^{M}$ et expression declined in the sui 2 cells but not in the gcd 10 cells. These data are consistent with the idea that gcd 10 mutants are defective in maturation of pretRN $A_{i}{ }^{\text {Met }}$ at $36^{\circ} \mathrm{C}$.

The dosage suppressors increase mature tRN ${ }_{i}{ }^{\text {Met }}$ levels in gcd10 mutants

It seemed likely that suppression of gcd10 mutations by hclMT genes occurred by increasing the abundance of mature tRN $A_{i}{ }^{M e t}$. In accordance with this expectation, we found that hclMT4 in the gcd10 mutant increased mature tRNA ${ }_{i}{ }^{\text {Met }}$ to levels exceeding that observed in the isogenic gcd10 transformant containing a low-copy plasmid bearing GCD 10 (Fig. 2A, cf. lanes 9-12 and lanes 5-8). The hclMT4 transformant also showed increased amounts of the smaller of two putative tRN $A_{i}{ }^{\text {Met }}$ precursors detected in the wild-type strain plus an even slower migrating species not detected in wild type (Fig. 2A, cf. lanes 9-12 and lanes 5-8, species c and a, respectively).

N orthern analysis of strains bearing hcl MT1, hcl MT2, hclMT3, or hcl MT4 suggests that the larger putative precursors seen in wild-type strains derive primarily from IMT2 and IMT3, whereas the smaller species are produced from IMT1 and IMT4 (Fig. 2B, species b and C, respectively). In addition, we confirmed that the putative precursor overexpressed in the hcl MT3 transformant hybridized with probes containing only the $5^{\prime}$ and $3^{\prime}$ terminal extensions encoded at IMT3, and that the putative precursor c hybridized with sequences derived from upstream of the IMT4-coding sequence (data not shown). The observed differences in pre-tRN $A_{i}{ }^{\text {Met }}$ sizes between the IMT genes can be explained by different locations of the transcription terminators either closer to (IMT1, IMT4) or farther away (IMT2, IMT3) from the 3' end of the mature tRNA. The hcIMT3 transformants contained relatively less mature tRN $A_{i}{ }^{\text {Met }}$ compared to the other hclMT transformants (Fig. 2B), which can explain why hclMT3 suppressed the phenotypes of gcd10-505 less completely than did the other three hcIMT genes (data not shown).

HCLHP1 also increased the level of precursor and mature tRN ${ }_{i}{ }^{\text {Met }}$ in the gcd10 mutant (Fig. 2A, lanes 1-4 vs. Ianes 13-16); however, mature tRN $A_{i}{ }^{\text {Met }}$ did not reach the wild-type level at $36^{\circ} \mathrm{C}$ (Fig. $2 \mathrm{~A}$, lane 16 vs. Iane 8), explaining why hcLHP1 only suppressed partially the ts $^{-}$phenotype of gcd10-504 (see Fig. 1A). HCLHP1 increased differentially the two precursor species detectable in wild type (species b and c) and al so led to the appearance of two novel species migrating slower than mature tRN $A_{i}{ }^{\text {Met }}$ (species $d$ and e). The presence of species $d$ and e suggests that Lhplp overexpression interferes with exonucleolytic trimming of pretRN $A_{i}{ }^{\text {Met }}$. There is evidence that Lhplp blocks exonucleolytic
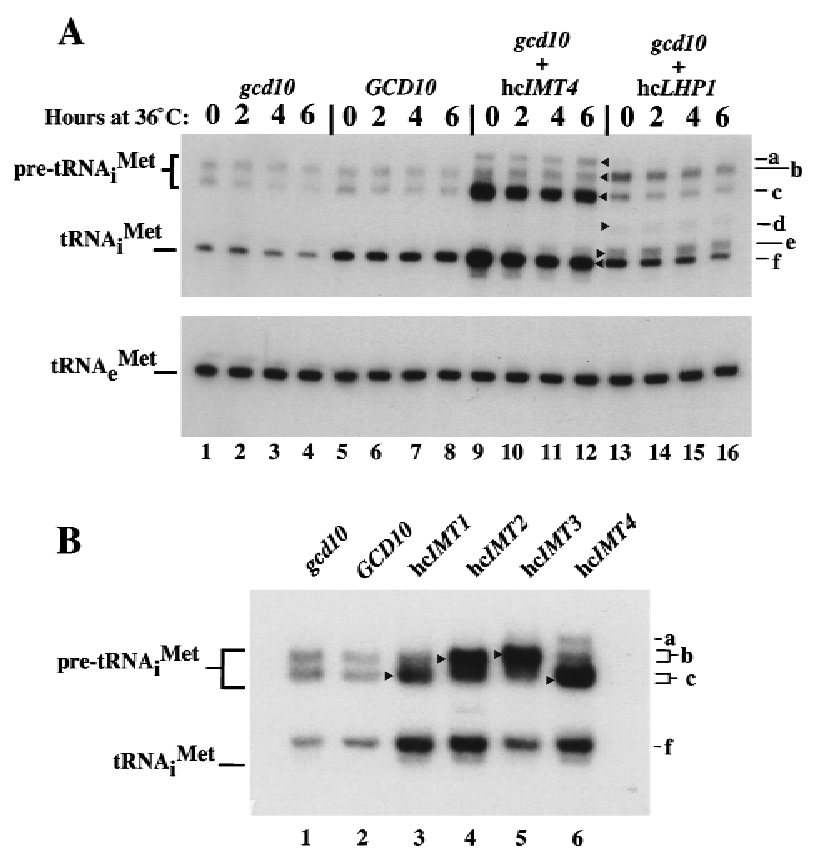

Figure 2. High-copy suppressors of gcd10 mutations lead to increased amounts of initiator tRN $A^{\text {Met }}$ and identification of pre-tRN $A_{i}{ }^{\text {Met }}$ species. (A) N orthern bl ot analysis of total RN A (5 $\mu \mathrm{g})$ isolated from transformants of strains $\mathrm{H} 2457$ (gcd10-504) carrying empty vector YEp24 (gcd10 lanes), low-copy plasmid pM G107 bearing GCD10 (GCD10 lanes), high-copy plasmid pC44 bearing IMT4 (gcd10 +hclMT4 lanes), or high-copy plasmid p2626 bearing LHP1 (gcd10 +hcLHP1 lanes), grown at $26^{\circ} \mathrm{C}$ or $36^{\circ} \mathrm{C}$ for the indicated times, as described in Fig. 1. The blot was probed for $\operatorname{tRN} A_{i}{ }^{\text {Met }}$ and stripped and reprobed for tRN $A_{e}{ }^{\text {Met }}$ as described in Fig. 1. Indicated with arrowheads inside the bl ot and label ed to the right are the presumed positions of pre-tRN $A_{i}{ }^{\text {Met }}$ containing $5^{\prime}$ and $3^{\prime}$ extensions encoded by IMT4 and terminating downstream of the usual termination site (a), pre-tRN $A_{i}{ }^{\text {Met }}$ containing $5^{\prime}$ and $3^{\prime}$ extensions encoded by IMT2 and IMT3 (b), pre-tRN $A_{i}{ }^{\text {Met }}$ containing $5^{\prime}$ and $3^{\prime}$ extensions encoded by IMT1 and IMT4 (c), processing intermediate of IMT3 containing the $3^{\prime}$ extension (d), processing intermediate containing partial $3^{\prime}$ extension (e), and mature tRN $A_{i}{ }^{\text {Met }}$ (f). (B) N orthern blot analysis of total RN A $(10 \mu \mathrm{g})$ isolated from H2457 (gcd10-504) transformants containing empty vector YEp24 (gcd10), low-copy plasmid pM G107 bearing GCD 10, or a high-copy plasmid bearing one of the four IMT genes, as indicated above the blot, grown at $26^{\circ} \mathrm{C}$ as described in Fig. 1. Initiator tRNAMet ${ }^{\text {Mas }}$ detected by hybridization as described above and in Fig. 1. Indicated with arrowheads inside the blot and labeled to the right are the positions of pre-tRN $A_{i}{ }^{M e t}$ containing $5^{\prime}$ and $3^{\prime}$ extensions $(a-c)$ and mature tRN $A_{i}{ }^{\text {Met }}$ (f), as in $\mathrm{A}$.

trimming and promotes endonucl eolytic cleavage of the $3^{\prime}$ trailer for certain other yeast tRN A families ( $Y$ oo and Wolin 1997). If this occurs for pre-tRN $A_{i}{ }^{\text {M et }}$ when Lhplp is overexpressed, it could be responsible for the higher levels of full-length pre-tRN $A_{i}{ }^{\text {Met }}$ and mature tRN $A_{i}{ }^{\text {Met }}$ seen under these conditions, provided that endonucleolytic cleavage is more precise than exonucleolytic trimming in 3 ' end maturation. 
GCD10 is nonessential in yeast strains overexpressing initiator tRNA ${ }^{\text {Met }}$

To test the possibility that overexpression of tRN $A_{i}{ }^{\text {Met }}$ would allow yeast cells to survive in the absence of Gcd10p, the gcd10 1 strain YJA 143 containing wild-type GCD10 on a URA3 plasmid (p2702) was transformed with a high-copy LEU 2 plasmid bearing IMT4 (p1775) (Dever et al. 1995). The URA3 GCD10 plasmid p2702 was readily eliminated from the resulting transformant by plasmid shuffling on medium containing 5-fluoroorotic acid (5-FOA) (Boeke et al. 1987), whereas p2702 could not be lost from isogenic transformants containing an empty LEU 2 vector. These results indicate that GCD 10 is dispensable in cells overexpressing tRN $A_{i}{ }^{M}$ et . We verified by immunoblot anal ysis that one such strain (YJA 146) containing hcl MT4 and lacking GCD10 had no detectable Gcd10p (data not shown).

Although the gcd10 $\Delta$ hclMT4 strain is viable, it grows poorly at temperatures $>26^{\circ} \mathrm{C}$ (Fig. 3A). We observed little difference in mature tRN $A_{i}{ }^{\text {M et }}$ levels between the isogenic gcd10 10 hclMT4 and GCD10 hclMT4 strains at $26^{\circ} \mathrm{C}$ (Fig. 3B, lanes 4,7 ). Thus, at low temperature, the requirement for $G C D 10$ in mature tRN $A_{i}{ }^{M}$ et expression appears to be largely bypassed by overproduction of tRNA ${ }_{i}{ }^{\text {Met }}$. In contrast, mature tRN $A_{i}{ }^{\text {Met }}$ was reduced substantially after 2 or $6 \mathrm{hr}$ at $36^{\circ} \mathrm{C}$ in the gcd $10 \Delta$ strain (Fig. 3B, lanes 5,6 vs. 8,9), showing that GCD10 is required for accumulation of mature tRNA ${ }_{i}{ }^{\text {et }}$ at $36^{\circ} \mathrm{C}$, even when tRN $A_{i}{ }^{M}$ et is being overexpressed. The gcd10 $\Delta$ hcIMT4 transformant accumulated higher levels of pretRNA ${ }_{i}{ }^{\text {Met }}$ than did the GCD10 hclMT4 transformant (Fig. 3B, cf. Ianes 4-6 and lanes 7-9), supporting the conclusion that Gcd10p is not required for efficient transcription of IMT4. In addition, the pre-tRN $A_{i}{ }^{\text {M et-to-ma- }}$ ture tRN $A_{i}{ }^{\text {Met }}$ ratio was much greater in the gcd10 $\Delta$ hclMT4 transformant compared to the GCD10 hcl MT4 strain, particularly at $36^{\circ} \mathrm{C}$ (Fig. 3B). It is al so noteworthy that the gcd10 $\Delta$ hclMT4 transformant accumulated species with mobilities greater than that of mature tRNA ${ }_{i}{ }^{\text {Met }}$, which were not observed in the GCD10 hclMT4 transformant (Fig. 3B, cf. Ianes 4-6 and lanes 7-9, species g). These observations suggest that Gcd10p is required for efficient processing of pre-tRN $A_{i}{ }^{M}$ et , particularly at el evated growth temperatures, and that in its absence, much of the unprocessed pretRN $A_{i}{ }^{\text {Met }}$ is degraded. The gcd10 $\Delta$ hcl MT4 transformant showed no detectable reduction in the accumulation of other mature

A
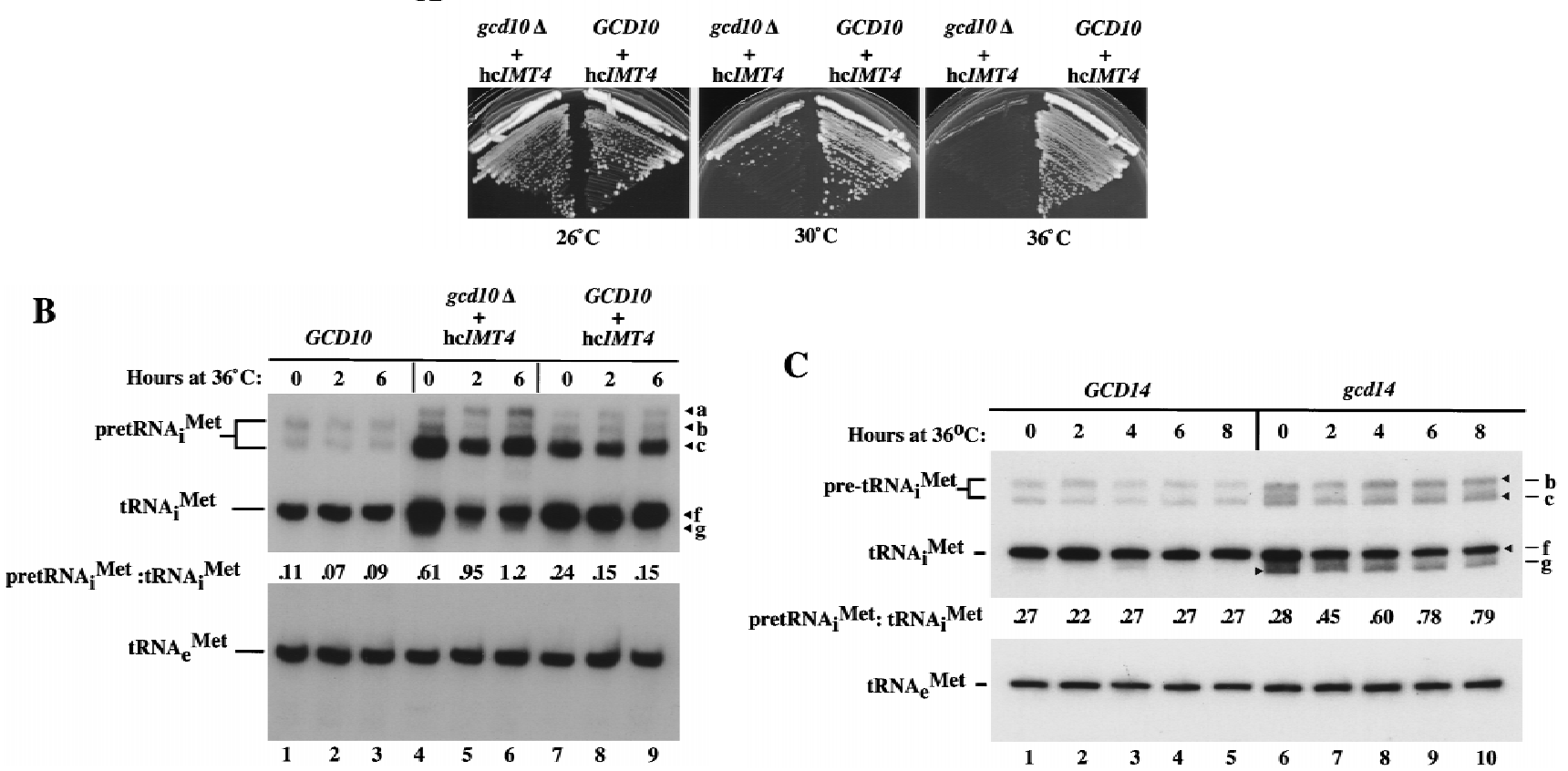

Figure 3. GCD10 is dispensable for cell viability in the presence of hclMT4. (A) Growth of strain YJA 146 (gcd104 +hclMT4) and a transformant of its parental GCD 10 strain BJ5464 bearing p1775 (GCD10 +hcl MT4) on YPD medium at $26^{\circ} \mathrm{C}$ for 3 days, and at $30^{\circ} \mathrm{C}$ or $36^{\circ} \mathrm{C}$ for 2 days. (B) N orthern blot analysis of total RN A $(7 \mu \mathrm{g})$ isolated from the same two strains described in A (gcd10 + hcl MT 4 and GCD 10 +hcl MT4 lanes) plus isogenic strain YJA 143 containing the gcd $10 \Delta$ chromosomal allele and single-copy GCD 10 plasmid p2704 (GCD 10). Strains were grown at $26^{\circ} \mathrm{C}$ or $36^{\circ} \mathrm{C}$ for 2 and $6 \mathrm{hr}$ as described in Fig. 1. The membrane was probed for tRN $A_{i}{ }^{\mathrm{Met}}$ and stripped and reprobed for tRN A ${ }_{e}{ }^{\text {et }}$ as described in Fig. 1 . The different RN A species detected are indicated at left. The various forms of tRN $A_{i}{ }^{\text {Met }}$ species are labeled at right as in Fig. 2, with the addition of species $\mathrm{g}$, which may be end-trimmed molecules lacking the CCA extension (see text). (C) N orthern bl ot analysis of total RNA (5 $\mu \mathrm{g}$ ) isolated from strain Hm296 (gcd14-2) containing wild-type GCD14 on single-copy plasmid pRC62 (GCD14 lanes) or empty vector YEp24 (gcd14 lanes), grown as described in Fig. 1. The membrane was probed for tRN $A_{i}{ }^{\text {Met }}$ and stripped and reprobed for tRN $A_{e}{ }^{\text {Met }}$ as described in Fig. 1 . Indicated with arrowheads inside the blot and label ed to the right are the various tRN $A_{i}{ }^{\text {Met }}$ species described in Fig. 2 and above. The indicated ratios of pre-tRN $A_{i}{ }^{\text {Met }}$ to mature tRN $A_{i}{ }^{\text {Met }}$ were calculated from the relative intensities of hybridization signals quantitated by Phosphorlmager analysis. 
tRN As when compared to the GCD10 + hclMT4 transformant, including tRNA $e^{\text {Met }}$ (Fig. 3B; tRNA $_{e}{ }^{{ }^{\text {et }}}$ ), tRN $A_{U A U}$ "le, and tRN A ${ }_{C G A}$ ser (data not shown).

Despite the reduction in mature tRN $A_{i}{ }^{\text {M et }}$ expression at $36^{\circ} \mathrm{C}$ in the $\operatorname{gcd} 10 \Delta$ hclMT4 transformant, it still maintained levels comparable to that seen in isogenic wild-type cells grown under the same conditions (Fig. 3B, cf. Iane 3 and lane 6, species $\mathrm{f}$ ). The presence of species $\mathrm{g}$ in the gcd10 $\Delta$ hclMT4 transformant at $36^{\circ} \mathrm{C}$ suggests that mature tRN $A_{i}{ }^{M}$ et is either unstable, or is processed or modified incompletely, and may not be fully functional in translation. This could explain the inviability of this strain at high temperatures without the need to propose a second function for Gcd10p.

gcd14 mutants are defective for processing of initiator tRNA ${ }^{\text {Met }}$ in vivo

gcd14 mutants exhi bit constitutivel y derepressed GCN 4 translation $\left(\mathrm{Gcd}^{-}\right)$and are temperature sensitive for general translation, the same phenotypes described for gcd10 mutations (Cuesta et al. 1998). In addition, any of the four I MT genes or LHPI on a high-copy plasmid suppressed the $\mathrm{Gcd}^{-}$and $\mathrm{ts}^{-}$phenotypes of gcdl4 mutants (R. Cuesta, O. Calvo, J. Anderson, M. Garcia-Barrio, A. Hinnebusch, and $M$. Tamame, in prep.). In accordance with these findings, we found that mature tRN $A_{i}{ }^{\text {M et }}$ decreased by a factor of 1.7 , whereas pre-tRN $A_{i}{ }^{\text {Met }}$ increased $\sim 1.5$-fold in a gcd 14-2 mutant after $8 \mathrm{hr}$ at $36^{\circ} \mathrm{C}$, increasing the ratio of precursor to mature tRN $A_{i}{ }^{\text {Met }}$ from 0.28 to 0.79 (Fig. 3C). These results suggest strongly that Gcd14p is required for processing of nascent tRN A $_{i}{ }^{\text {Met }}$ transcripts. Interestingly, a tRN $A_{i}{ }^{\text {Met }}$ species migrating faster than the wild-type mature form, exhibiting a similar mobility to the aberrant tRN $A_{i}{ }^{\text {Met }}$ seen in the gcd10 $\Delta$ hclMT4 transformants, is present in the gcd14-2 mutant under all conditions (Figs. 3B,C, species g). Thus, 5' - and 3'-trimmed tRN $A_{i}{ }^{\text {M et }}$ may be unstable, or incorrectly processed or modified, in gcd14-2 cells. As in the case of gcd10-504, the gcd14-2 mutation had no effect on the level or apparent length of elongator tRN A ${ }^{M \text { et }}$ (Fig. 3C).

Gcd10p is required for the stability of total tRNA ${ }_{i}{ }^{\text {Met }}$ in vivo

We used pulse-chase analysis to investigate whether the reduced amount of mature tRN $A_{i}{ }^{\text {Met }}$ in the gcd10-504 mutant results from rapid degradation of $\operatorname{tRN~} \mathrm{A}_{\mathrm{i}}{ }^{\mathrm{M} \text { et }}$ transcripts. After incubating isogenic GCD 10 and gcd10-504 strains for $\sim 2 \mathrm{hr}$ at $36^{\circ} \mathrm{C}$, cells were pulse-labeled with $\left[{ }^{3} \mathrm{H}\right.$ ] uracil for $1 \mathrm{hr}$, and chased for $5 \mathrm{hr}$ with excess unlabeled uracil. Total RN A was isolated at different times and aliquots containing equival ent amounts of radioactivity were hybridized to immobilized oligonucleotides complementary to initiator tRN $A^{M \text { et }}$ or elongator tR$\mathrm{NA}^{\mathrm{Met}}$. The proportion of ${ }^{3} \mathrm{H}$-labeled tRN $\mathrm{A}_{e}{ }^{\mathrm{Met}}$ in both mutant and wild-type cells, and of tRN $A_{i}{ }^{M}$ et in the wildtype strain, showed a small increase over the 5-hr chase period (Fig. 4A). Presumably, these increases occurred because the pool of uracil nucleotides chased slowly, allowing the proportion of label in stable RN A to increase relative to unstable $\mathrm{mRNA} A$. In contrast, the proportion of ${ }^{3} \mathrm{H}$-labeled tRN $A_{i}{ }^{\text {Met }}$ in the gcd10 mutant dropped by a factor of about two during the first hour of the chase and showed little additional change throughout the remaining 4-hr chase period (Fig. 4A). These results indicate that a large fraction of $\operatorname{tRN~} A_{i}{ }^{\text {M et }}$ transcripts made during the 1-hr pulse in the gcd10 mutant was very unstable, whereas the remainder was highly stable. As expected, the gcd10 mutation had no effect on the turnover of tRNA $e^{\text {Met. }}$.

It seemed likely that the unstable pool of tRN $A_{i}{ }^{\text {Met }}$ transcripts detected by pulse-chase analysis in the gcd10-504 mutant represented nascent tRN $A_{i}{ }^{\text {Met }}$ molecules that were degraded rapidly in the nucleus. To eliminate the alternative possibility that mature $\operatorname{tRN~A}_{i}{ }^{\text {Met }}$ is unstable, we treated gcd10 $\Delta$ and gcd10-504 cells with an inhibitor of Pol III transcription, thiolutin (Jimenez et al. 1973), coincident with the shift to $36^{\circ} \mathrm{C}$ to prevent cell division and new synthesis of pre-tRN $A_{i}{ }^{\text {M et }}$ transcripts at the nonpermissive temperature. As shown in Figure 4B, the untreated gcd10 $\Delta$ and gcd10-504 cells showed the usual reduction in mature tRN $A_{i}{ }^{\text {Met }}$ after the temperature shift (lanes 1-4 and 8-11). In contrast, thiolutin treatment largely eliminated the reduction in mature tR N $A_{i}{ }^{\text {et }}$ levels at $36^{\circ} \mathrm{C}$ (Fig. 4B, lanes 5-7 and 12-14). The disappearance of pre-tRN $A_{i}{ }^{\text {Met }}$ species after thiolutin treatment is the expected result of inhibiting IMT transcription without preventing processing (or degradation) of the preexisting pre-tRN $\mathrm{A}_{\mathrm{i}}{ }^{\mathrm{Met}}$ transcripts. The fact that little or no change in mature tRN $A_{i}{ }^{\text {Met }}$ abundance occurred at $36^{\circ} \mathrm{C}$ in the presence of thiolutin suggests that the mature tRN $A_{i}{ }^{M}$ et present at the temperature shift is stable in gcd10-504 cells. The gcd10-504 mutant continues to grow at $36^{\circ} \mathrm{C}$, al beit more slowly than the wild type, doubling in mass $\sim 2.5$ times after the temperature shift. Thus, the reduction in mature tRNA ${ }_{i}{ }^{\text {Met }}$ seen in the absence of thiolutin most likely occurs by dilution of stable preexisting mature tRN $A_{i}{ }^{\text {Met }}$, coupled with a failure to produce new mature tRNA ${ }_{i}{ }^{M e t}$ during cell divisions at the nonpermissive temperature. We suggest that the unstable $\operatorname{tRNA_{i}}{ }^{M e t}$ molecules detected by pul se-chase analysi s in the gcd 10504 mutant (Fig. 4A) are primarily nascent transcripts that are rapidly degraded in the nucleus.

Evidence that Gcd10p and Gcd14p are components of a heteromeric nuclear complex

To investigate whether Gcd10p and Gcd14p are physically associated in vivo, we constructed a yeast strain expressing a polyhisti dine-tagged form of Gcd10p (HisGcd10p) to al low affinity purification of the protein. The GCD10-His allele encoding His-Gcd10p was indistinguishable from wild-type GCD10 in complementing gcd 10 mutations in vivo (see $M$ aterials and $M$ ethods). As shown in Figure 5A, substantial fractions of both Gcd14p and Gcd10p in whole cell extracts were eluted from 
Figure 4. Evidence that newly synthesized initiator tRN $A^{\text {M et }}$ is unstable in gcd10 mutants. (A) Transformants of strain H2457 (gcd10-504) bearing the GCD10 plasmid pMG107 (GCD10) or vector YEp24 (gcd10-504) were grown in supplemented SD medium at $36^{\circ} \mathrm{C}$ for $2.25 \mathrm{hr}$ before the addition of $5.0 \mathrm{mCi}[5,6-3 \mathrm{H}]$-uracil $(37 \mathrm{Ci} / \mathrm{mmole}, 1 \mathrm{mCi} / \mathrm{ml} \mathrm{NEN})$. Cells were continuously labeled at $36^{\circ} \mathrm{C}$ for $60 \mathrm{~min}$ (pulse) after which 200 -fold excess unlabeled uracil was added and incubation at $36^{\circ} \mathrm{C}$ was continued for $5 \mathrm{hr}$ (chase). Total RNA was isol ated from 2.0-ml al iquots at 0, 1, 3, and $5 \mathrm{hr}$ after addition of unlabeled uracil and an amount of RNA representing equal cpms was hybridized to membrane-bound oligonucleotides complementary to full-length $\operatorname{tRNA}_{i}{ }^{\text {Met }}$ (top) and tRNA ${ }_{e}^{\text {Met }}$ (bottom) in hybridization solution $[500 \mathrm{~mm} \mathrm{NaCl}, 24 \mathrm{~mm}$ $\mathrm{NaH}_{2} \mathrm{PO}_{4}, 2.4 \mathrm{~mm}$ EDTA (pH 7.4), $30 \%$ formamide, 5× Denhardt's solution, $0.1 \%$ SDS] at $40^{\circ} \mathrm{C}$ for 2.5 days with constant mixing. After hybridization, filters were washed once in hybridization solution at $40^{\circ} \mathrm{C}$ for $30 \mathrm{~min}$, once in $2 \times \mathrm{SSC}, 0.1 \%$ SDS for $30 \mathrm{~min}$ at room temperature, once in $2 \times \mathrm{SSC}$ for $30 \mathrm{~min}$, and twice with $95 \%$ ethanol. Filters were dried and counted by liquid scintillation in Econo-fluor (Packard Chemical). The cpm bound to the membranes at each time point were corrected by subtracting the cpm bound to a third membrane containing a nonspecific oligonucleotide. The corrected counts per minute are expressed as the percentage of cpm bound to the membrane at the beginning of the chase (time $=0$ ). (B) Strains YJA146 (gcd10 10 hclMT4) and a transformant of H2457 containing vector YEp24 (gcd10-504 +YEp24) were grown to mid-exponential phase at $26^{\circ} \mathrm{C}$ in SC or minimally supplemented SD medium and resuspended in the same medium prewarmed to $36^{\circ} \mathrm{C}$ containing $5 \mu \mathrm{g} / \mathrm{ml}$ thiolutin in DMSO or DMSO only. N orthern blots of total RNA $(10 \mu \mathrm{g})$ isolated from the strains at $26^{\circ} \mathrm{C}$ $\left(0 \mathrm{hr}\right.$ at $\left.36^{\circ} \mathrm{C}\right)$ or $36^{\circ} \mathrm{C}\left(4,8,12 \mathrm{hr}\right.$ at $\left.36^{\circ} \mathrm{C}\right)$ with $(+)$ or without $(-)$ thiolutin treatment were probed with a label ed ol igonucleotide that specifically hybridized to both pre-tRN $A_{i}{ }^{\text {Met }}$ and mature $\operatorname{tRNA} A_{i}{ }^{\text {Met }}$, as described in Fig. 1. Labeled at right are various $\operatorname{tRNA}{ }_{i}{ }^{\text {Met }}$ species described in Figs. 2 and 3.

$\mathrm{Ni}^{+2}-\mathrm{NTA}$ agarose with the GCD10-His extract but not with the isogenic GCD 10 extract. In contrast, the PRT 1encoded subunit of elF3 ( $\mathrm{N}$ aranda et al. 1994) in both extracts did not bind to the resin. These findings indicate that Gcd10p and Gcd14p are components of a heteromeric complex that is not stably associated with elF3.

As most steps in tRNA processing are believed to occur in the nucleus (Hopper and Martin 1992), we used indirect immunofluorescence to determine whether Gcd10p and Gcd14p are nuclear proteins. Toward this end, we constructed alleles of GCD10, GCD14, and TIF34 (encoding the 39-kD subunit of yeast elF3; $\mathrm{N}$ aranda et al. 1997) tagged with the coding sequences for three tandem copies of the HA epitope. The tagged alleles were introduced on low-copy plasmids into yeast strains either lacking the cognate chromosomal allele, in the case of GCD 10-HA (YJA 142) and TIF34-HA (KAY8), or containing a temperature-sensitive allele in the case of GCD14-HA (see Materials and Methods). All three tagged al leles complemented the lethal effects of mutations in the corresponding genes as effectively as did the wild-type al leles (data not shown). In addition, thetagged proteins were expressed at levels similar to that of the wild-type proteins (data not shown). As expected for an
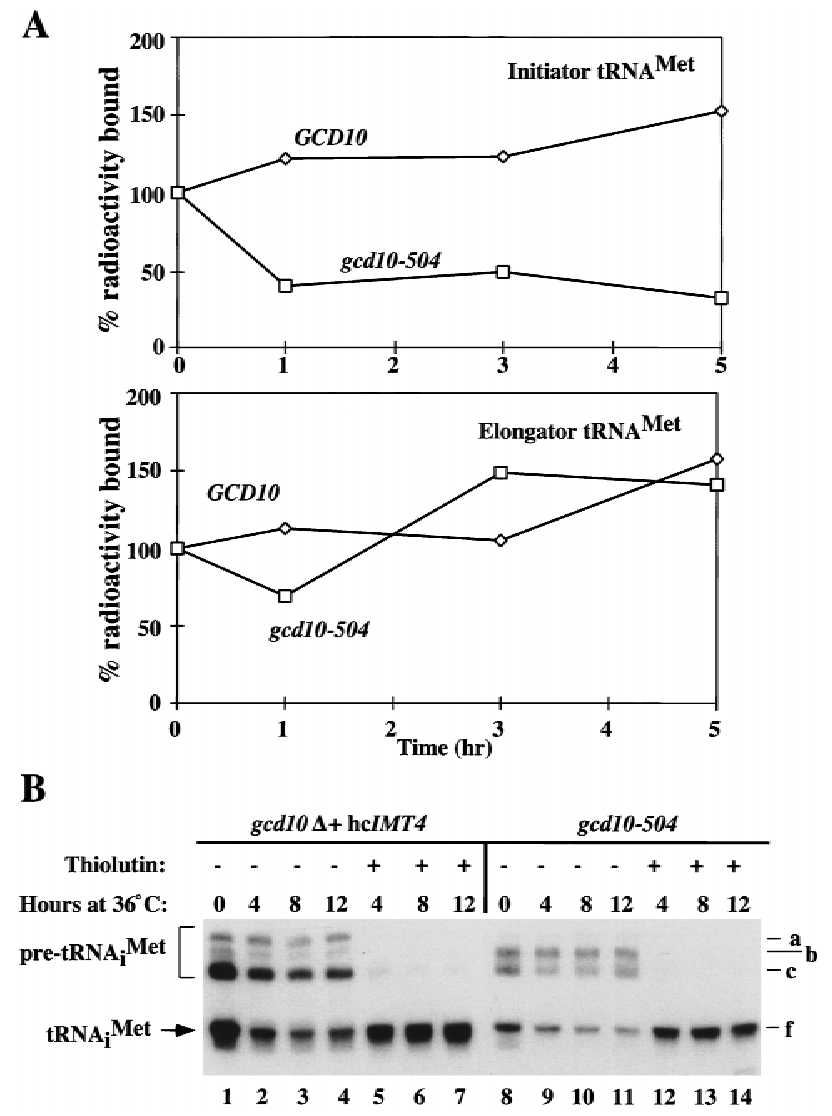

integral subunit of elF3, HA-Tif34p was found exclusively in the cytoplasm (Fig. 5B, k), whereas $\mathrm{Nablp}$ showed diffuse nuclear staining characteristic of a nucleoplasmic protein (panel e) (Wilson et al. 1994). Both HA-Gcd10p and HA-Gcd14p showed prominent nucl ear localization with staining indicative of nucleoplasmic factors (Fig. 5B, a,g). Because of the background staining with anti-HA antibodies of the control GCD10 and GCD14 strains (Fig. 5B, c,i), it was not possible to determine whether Gcd10p and Gcd14p are located in the cytoplasm in addition to the nucleus.

Gcd10p is required for the 1-methyladenosine modification of initiator tRNA ${ }^{\text {Met }}$ at position 58

Gcd14p exhibits significant homology with S-adenosylmethionine-dependent methyltransferases (R. Cuesta, O. Calvo, J. Anderson, M. Garcia-Barrio, A. Hinnebusch, and $M$. T amame, in prep.), suggesting the possibility that Gcd10p and Gcd14p are required for tRN $A_{i}{ }^{\text {Met }}$ methylation. To test this idea, total tRN A isol ated from gcd $10 \Delta$ and wild-type strains was aminoacylated with $\left[{ }^{35} \mathrm{~S}\right] \mathrm{me}$ thi onine or $\left[{ }^{3} \mathrm{H}\right]$ methionine, respectively, and the labeled 

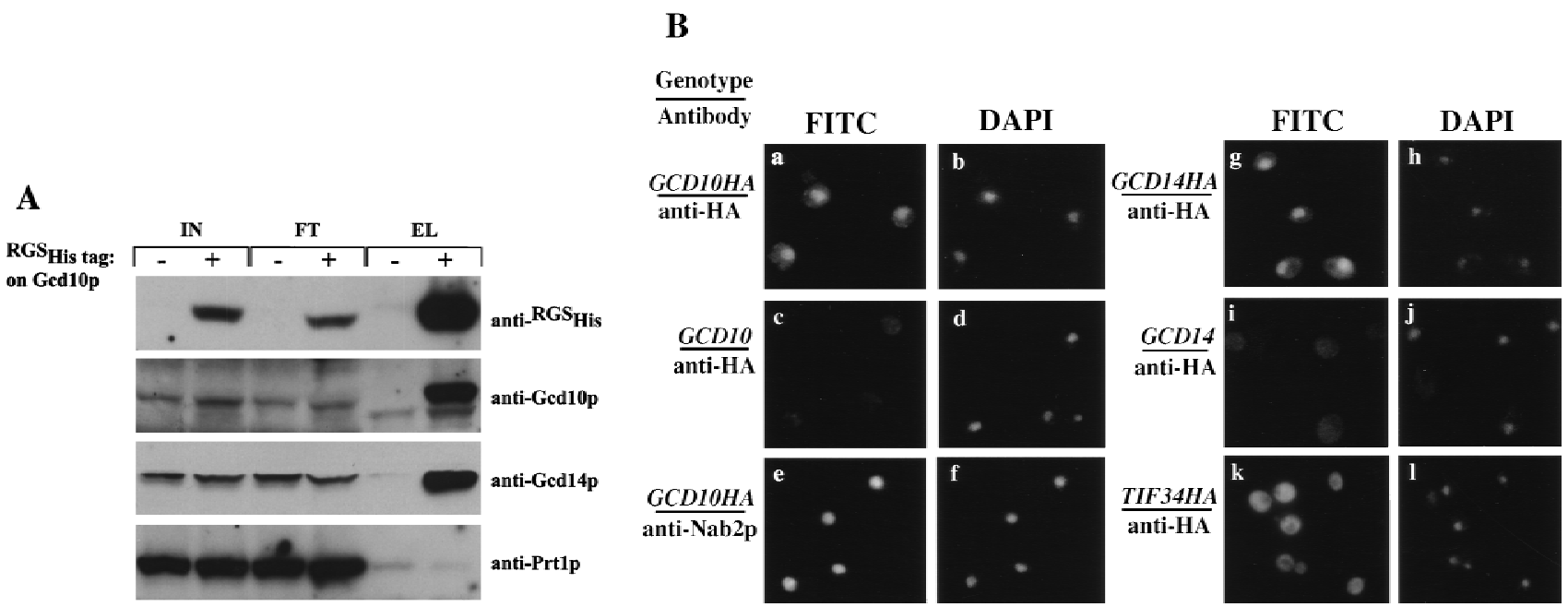

Figure 5. Gcd10p and Gcd14p form a stable nuclear complex in vivo. (A) Whole cell extracts were prepared from isogenic strains LPY 251 (GCD 10) and LPY 252 (GCD 10-His) containing wild-type and His-tagged Gcd10p, respectively, as described (Phan et al . 1998). Each clarified extract was batch-bound to $50 \mu \mathrm{l}$ of $\mathrm{Ni}^{2+}$-agarose (Qiagen) in $\mathrm{H}_{2} \mathrm{O}(50 \% \mathrm{vol} / \mathrm{vol})$ for $1 \mathrm{hr}$ at $4^{\circ} \mathrm{C}$. Proteins bound to $\mathrm{Ni}^{2+}$-agarose were collected by centrifugation at $3000 \mathrm{rpm}$ for $2 \mathrm{~min}$, washed four times with $300 \mu$ l of breaking buffer, and batcheluted with $50 \mu \mathrm{l}$ of breaking buffer containing $250 \mathrm{~mm}$ imidazole. Aliquots containing $10 \%$ of the input cell extracts (IN), $10 \%$ of the flowthrough wash (FT), and $100 \%$ of the eluate (EL) were resolved by SDS-PAGE and subjected to immunoblot analysis using monoclonal anti- ${ }^{\mathrm{RGS}} \mathrm{His}$ antibodies (1:500; Qiagen) directed against the tag on His-Gcd10p, and with polyclonal antibodies directed against Gcd10p (1:500), Gcd14p (1:500), or Prt1p(1:1000). (B) Indirect immunofluorescence was used to study the subcellular distribution of HA epitope-tagged forms of Gcd10p, Gcd14p, and Tif34p in strains YJA 142 (GCD10-HA; a,b), YJA143 (GCD10; c,d), Hm296 bearing pRC64 (GCD14-HA; g,h), Hm296 bearing pRC62 (GCD 14; i,j), and KAY 8 (TIF34-HA; k,I), as described previously (Anderson et al. 1993). All antibodies were diluted in PBS, $5 \%$ non-fat dried milk. The affinity-purified 12 CA5 monoclonal antibody against the HA epitope (at $20 \mu \mathrm{g} / \mathrm{ml}$; Boehringer Mannheim) was used to probe strains expressing HA-tagged proteins and the isogenic control strains lacking tagged proteins (a,c,g,i,k). M onoclonal antibody $1 E 4$ (at 1:750 dilution; Wilson et al. 1994) was used to detect $\mathrm{N}$ ablp in strain YJA142 (e). Detection of the primary antibodies was accomplished using a fluorescein isothiocyanate (FITC)-conjugated secondary antibody $(a, c, e, g, i, k)$ and the DNA distribution was visualized by DAPI $(b, d, f, h, j, l)$.

tRNAs were chromatographed on a RPC-5 column (Kelmers and Heatherly 1971). It was shown previously that this technique can resolve tRN As that differ by only a single methyl group (Diamond et al. 1993). As shown in Figure 6A, wild-type tRN A contains two peaks of methionine-accepting tRN As corresponding to initiator (fractions 20-40) and elongator tRN A ${ }^{\text {Met }}$ (fractions 95120) (D. Hatfield, unpubl.). In the gcd10 $\Delta$ tR N A, the majority of both initiator and elongator methionyltRN $A^{\text {M et }}$ were resolved into single peaks that el uted in later fractions than did the same isoacceptors from the wild type. The differences in methionyl-tRNA ${ }^{\text {Met }}$ elution profiles might arise from differences in tRNA length, although this seems unlikely for the $3^{\prime}$ end because of the obligatory requirement of CCA termini for aminoacylation. In addition, we observed no differences in length of initiator or elongator $\operatorname{tRNA}^{\mathrm{Met}}$ between GCD 10 and gcd $10 \Delta$ tRN As after separation on high resoIution polyacrylamide gels and $\mathrm{N}$ orthern blot analysis (data not shown). Together, these results provide strong evidence that $\mathrm{G} c d 10 p$ and $\mathrm{G} c d 14 p$ are required for modifying one or more bases in both forms of tRN $A^{\text {M et. Smal I }}$ amounts of the initiator and elongator methionyl-tRN As from gcd10 $\Delta$ cells el uted earlier (i i itiator) or later (elongator) than the major peaks (Fig. 6A). These mi nor peaks may represent methionine-accepting tRN As lacking additional modifications, or exhibiting a collapsed tertiary structure, due to the absence of a Gcd10p-dependent modification.

To examine directly whether the methionyl-tRN As from gcd $10 \Delta$ cells lack a modified base, total tRN A from the GCD 10 and gcd10 1 strains was digested completely to nucleosides and separated by high-performance liquid chromatography (HPLC) (Gehrke and Kuo 1990). The resulting chromatograms were identical except for the absence of a single peak in the gcd10 $\Delta$ sample with a retention time of $13.5 \mathrm{~min}$, identified previously as 1-methyl adenosine (Gehrke and Kuo 1990) (Fig. 6B). This assi gnment was confirmed in two ways. First, addition of synthetic $\mathrm{m}^{1} \mathrm{~A}$ to wild-type or gcd10 $\Delta$ tRN A hydrolyzates followed by HPLC analysis restored the missing peak to the gcd10 $\Delta$ sample and led to a quantitative increase in the corresponding peak in the wild-type sample (data not shown). Second, the nucleoside present in the peak eluting at $13.5 \mathrm{~min}$ had the UV spectrum of $\mathrm{m}^{1} \mathrm{~A}$ (Gehrke and Kuo 1990) and the same molecular mass as protonated $\mathrm{m}^{1} \mathrm{~A}$ (282 Da) as determined by mass spectrometry using ionization electrospray (data not shown). These results strongly suggest that Gcd10p is required for the formation of 1-methyladenosine in tRN A. This base modification occurs at position 58 in initiator and elongator tRN $A^{\text {Met }}$ and in 16 other tRNAs, but is not found at any other positions in yeast tRN As (Sprinzl et al. 1998). 
A

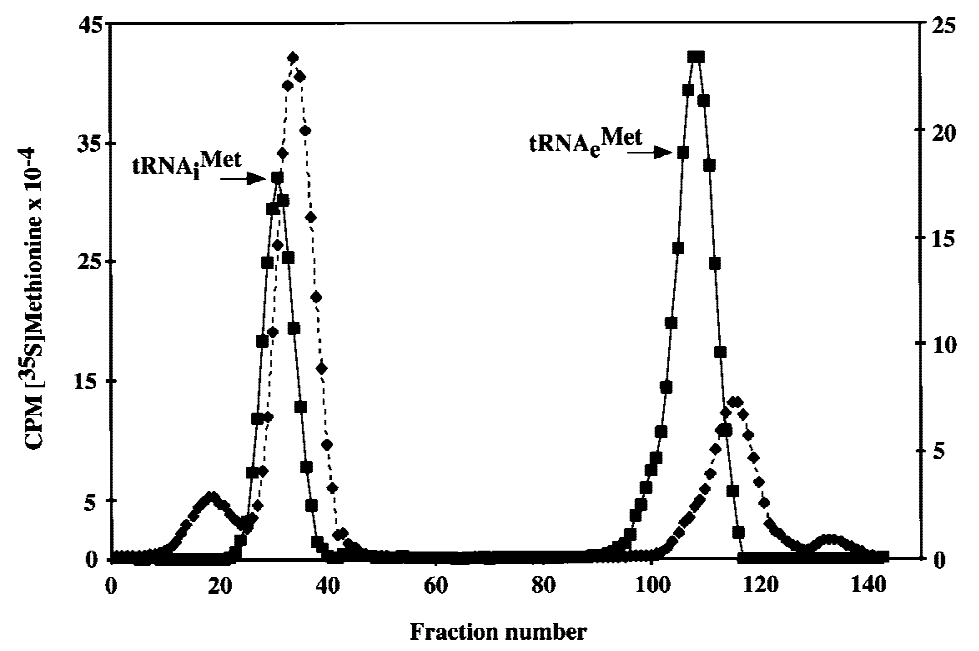

B

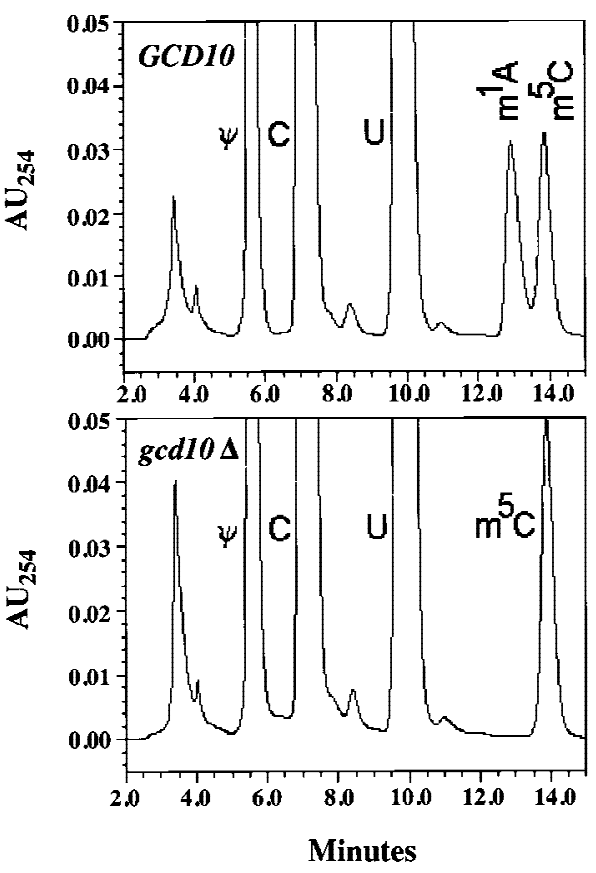

Figure 6. Evidence that methionine-accepting and other tRN As from a gcd10 $\Delta$ strain are hypomethylated. (A) Total tRN A isolated from YJA 146 (gcd10 4 ) and the p1775 transformant of Bj5464 (GCD10) was aminoacylated with $\left[{ }^{35}\right.$ S]methionine and $\left[{ }^{3} \mathrm{H}\right.$ ]methionine, respectively, and 500,000 cpm of each were chromatographed on a RPC-5 column. The radioactivity in each fraction (0.6 ml) was measured by liquid scintillation in $7 \mathrm{ml}$ of Ecoscint $\mathrm{A}$ ( $\mathrm{N}$ ational Diagnostics) and is plotted on different $\mathrm{y}$-axes, as shown, against the fraction number. ( $\square$ ) Results obtained with wild-type tRN A (GCD10); ( ) results with gcd10 $\Delta$ tRN A. The elution positions of the methionine-accepting tRN As are indicated at the appropriate positions. (B) Transfer RN As were digested to nucleosides and chromatographed by HPLC on a Supel cosil LC-18S column. Only the portion of the chromatogram (corresponding to retention times of 2-14.5 min) showing a difference between the GCD10 and gcd10 samples is shown here. The peak that is absent in the gcd10 $\Delta$ sample was identified as $\mathrm{m}^{1} \mathrm{~A}$ by several means (see text). The identities of other peaks in this portion of the chromatogram are

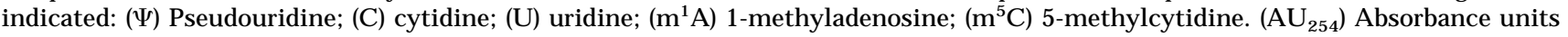
at $254 \mathrm{~nm}$.

\section{Discussion}

Previously, we identified Gcd10p genetical ly as a factor required for translational repression of GCN4 mRNA, indicating a role in the formation or utilization of ternary compl exes. Using suppressor analysis, we have uncovered a function for Gcd10p in tRN $A_{i}{ }^{\text {Met }}$ maturation. After discovering that gcd10 mutations can be suppressed by extra copies of the IMT or LHP1 genes, we found that the level of mature tRN $A_{i}{ }^{\text {Met }}$ was reduced in a gcd10-504 mutant (Fig. 1). This was also true of a gcd14-2 mutant (Fig. 3C), which exhibits the same defect in GCN 4 translation seen in gcd10 mutants (Cuesta et al. 1998) and can al so be suppressed by hcl MT or hcLHP1 (R. Cuesta, O. Calvo, J. Anderson, M. Garcia-Barrio, A. Hinnebusch, and $M$. Tamame, in prep.). The reductions in mature tRN $A_{i}{ }^{\text {Met }}$ levels in these mutants can be expected to diminish ternary complex formation, explaining their constitutive derepression of GCN 4 translation. It was striking that overexpression of tRN $A_{i}{ }^{\text {Met }}$ suppressed the lethal ity of a gcd10 $\Delta$ deletion (Fig. 3A), indicating that the essential function of GCD10 is to promote expression of mature tRN $A_{i}{ }^{\text {Met }}$. In addition to the genetic links between Gcd10p and Gcd14p, both pro- teins show prominent nuclear localization (Fig. 5B) and are components of the same heteromeric protein complex (Fig. 5A; R. Cuesta, O. Calvo, J. Anderson, M. Garcia-Barrio, A. Hinnebusch, and M. Tamame, in prep.).

The gcd10-504 mutation did not lead to accumulation of pre-tRNA ${ }_{i}{ }^{\text {Met }}$ or the appearance of novel tRNA ${ }_{i}{ }^{\text {Met }}$ species, but only to reduced amounts of mature tRNA ${ }_{i}{ }^{\text {Met }}$ (Fig. 1B). On the basis of the results of pulsechase experiments indicating that a large fraction of newly synthesized tRN $A_{i}{ }^{\text {Met }}$ is unstable in gcd10-504 cells (Fig. 4), we concluded that the decrease in mature $\operatorname{tRNA_{i}}{ }^{\text {Met }}$ arose from increased degradation rather than diminished synthesis of pre-tRN $A_{i}{ }^{\text {Met }}$. This conclusion is consistent with our finding that in vitro transcription of IMT4 occurred at the same rates in extracts from $\operatorname{gcd} 10 \Delta$ and GCD10 strains (J. Anderson and A.G. Hinnebusch, unpubl.). In the gcd14-2 mutant, accumulation of pre-tRN $A_{i}{ }^{\text {Met }}$ species containing both $5^{\prime}$ and $3^{\prime}$ extensions, plus an aberrant species shorter than mature tRN $A_{i}{ }^{\text {Met }}$ were observed in addition to a specific reduction in the amount of mature tRN $A_{i}{ }^{\text {Met }}$ (Fig. $3 C$ ). These findings strongly suggest that processing of pretRNA ${ }_{i}{ }^{\text {Met }}$ is impaired by gcd14-2. Similar phenotypes were observed in the gcd10د hclMT4 strain (Fig. 3B). 
Considering that $\mathrm{Gcd} 10 \mathrm{p}$ and $\mathrm{Gcd} 14 \mathrm{p}$ reside in the same complex, deletion of GCD10 may indirectly impair Gcd14p function. Because cl eavage of the 5' extension by RN ase $P$ general ly precedes trimming of the $3^{\prime}$ extension (O'Connor and Peebles 1991), accumulation of pretRN $A_{i}{ }^{\text {Met }}$ in gcd14-2 and gcd10 $\Delta$ hcl MT4 cells containing both $5^{\prime}$ and $3^{\prime}$ extensions (species b and c) suggests that trimming by RNase $P$ occurs more slowly in these mutants. The predicted length of the novel tRN $A_{i}{ }^{\text {Met }}$ that migrates faster than mature tRN $A_{i}{ }^{\text {Met }}$ (species $\mathrm{g}$ ) is consistent with tRN As lacking the 3' CCA. Thus, it is possible that CCA addition al so occurs less efficiently in gcd 14-2 and gcd10 $\Delta$ hcl MT4 strains. We observed no significant differences in the rate of IMT3 transcription or the efficiency of pre-tRNA ${ }_{i}{ }^{\text {Met }}$ processing between gcd14-2 and GCD 14 extracts (). Anderson and A.G. Hinnebusch, unpubl.), providing evidence that Gcd14p is not required for $5^{\prime}$ - or $3^{\prime}$-end trimming of pre-tRN $A_{i}{ }^{\text {Met }}$ in vitro.

The fact that I arge fractions of Gcd10p and Gcd14p are found in the nucleus, where enzymes involved in modification (Rose et al. 1995; Si mos et al . 1996) and processing (Clark and Abelson 1987) of tRN As generally reside, suggests that they function directly in one or more aspects of tRN $A_{i}{ }^{\text {Met }}$ maturation. Gcd14p contains motifs (Kagan and Clarke 1994) common to S-adenosylmethionine-dependent methyltransferases (Cuesta et al. in prep.), raising the possibility that it methylates one of the bases in tRN $A_{i}{ }^{\text {Met }}$. Experimental support for this hypothesis came from our finding that both initiator and elongator tRNA ${ }^{\text {Met }}$ isolated from gcd10 $\Delta$ cells eluted from a RPC -5 column in different positions than did the corresponding tRN As from wild-type cells (Fig. 6A). As there are only four base methylations common to initiator and el ongator methionine tRNAs, $\mathrm{m}^{2} \mathrm{G} 10, \mathrm{~m}^{7} \mathrm{G} 46$, $\mathrm{m}^{5} \mathrm{C} 48$, and $\mathrm{m}^{1} \mathrm{~A} 58$ (Sprinzl et al. 1998), these results led to the prediction that the Gcd10p-Gcd14p complex is required for one of these modifications. Analysis of all modified nucleosides in total tRNA (Fig. 6B) indicated that 1-methyladenosine, found at position 58 in 18 yeast tRN As, was undetectable in gcd10 $\Delta$ cells. Recently, we repeated the HPLC analysis of modified nucleosides in purified intitiator tRN $A^{M \text { et }}$ and again failed to detect $\mathrm{m}^{1} \mathrm{~A}$ (J. Anderson, G.R. Björk, and A.G. Hinnebusch, unpubl.). Thus, we conclude that initiator tRN $A^{M e t}$ produced in gcd10 $\Delta$ cells lacks $\mathrm{m}^{1} \mathrm{~A} 58$. Importantly, this residue plays a central role in determining a unique tertiary substructure not observed in elongator tRN As, involving three residues unique to eukaryotic initiators, A60, A54, and A 20 (Basavappa and Sigler 1991). Therefore, the absence of this modification might alter the tertiary structure of the initiator, and impair its processing and stability, without similarly affecting el ongator tRN $A^{M \text { et }}$ and other tRN As bearing ${ }^{1}{ }^{1} A 58$. Several of the genes that function in modifying tRNAs have been cloned and none is essential for cell viability (Hopper and Martin 1992). If the Gcd10p-Gcd14p complex functions only in the production of $\mathrm{m}^{1} \mathrm{~A} 58$, this would be the first instance of an essential tRN A modification in yeast.

In addition to showing a defect in processing, it ap- pears that unprocessed pre-tRNA ${ }_{i}{ }^{\text {Met }}$ molecules are degraded more rapidly in gcd10 $\Delta$ mutants. These results suggest that Gcd10p is required to protect hypomethylated pre-tRN $A_{i}{ }^{\text {Met }}$ from degradation in addition to promoting the function of Gcd14p in $m^{1} A 58$ formation. The maturation of tRN $A_{i}{ }^{M \text { et }}$ occurs very inefficiently in gcd10 $\Delta$ hclMT4 cells grown at $36^{\circ} \mathrm{C}$, such that mature tRN $A_{i}{ }^{M}$ et is not overproduced despite the increased copy number of IMT4 (Fig. 3B, cf. Ianes 2 and 3 with Ianes 5 and 6). This finding is consistent with the idea that Gcd10p stabilizes the conformation of hypomethylated pre-tRN $A_{i}{ }^{\text {Met }}$, as the absence of Gcd10p would be expected to have more severe consequences at elevated temperatures where isomerization of pre-tRNA ${ }_{i}{ }^{\text {et }}$ to aberrant conformations should be favored. Furthermore, Gcd10p has strong RN A-binding activity (Garcia-Barrio et al. 1995), which might enable it to perform this proposed RN A chaperone function.

Recently, it was proposed that Lhplp functions as an RNA chaperone in facilitating endonucleolytic trimming of the $3^{\prime}$ trailers of many yeast pretRNAs. Through binding to the poly $(U)$ stretch at the $3^{\prime}$ end of pre-tRNA, Lhplp would stabilize the conformation needed for endonucleolytic 3'-trimming and block access by $3^{\prime} \rightarrow 5^{\prime}$ exonucleases (Yoo and Wolin 1997). Interestingly, a mutation in yeast tRN $A_{C G A}$ Ser that renders its processing dependent on Lhplp leads to degradation of processing intermediates when Lhplp is depleted from cells (Yoo and Wolin 1997). This might resemble the situation in gcd10 $\Delta$ mutants where the absence of $m^{1} A 58$, combined with loss of the putative Gcd10p chaperone function, would result in degradation of pre$\operatorname{tRNA}_{i}{ }^{\text {Met }}$. Perhaps overexpression of Lhplp in gcd10 mutants allows it to substitute partially for the chaperone function of Gcd10p, increasing the probability of accurate processing and protecting the hypomethylated pre-tRN $A_{i}{ }^{\text {M et }}$ from degradation.

It is conceivable that Gcd10p accompanies mature tRN $A_{i}{ }^{\text {Met }}$ from the nucleus to the cytoplasm, where it could promote formation of ternary complexes with elF2 and GTP. This could explain why it copurified with elF3 activity through several chromatographic separations (Garcia-Barrio et al. 1995), as stabi lizing the ternary complex is one function ascribed to elF3 (Peterson et al. 1979). Although we did not observe a stable interaction between Gcd10p and the PRT1 subunit of elF3 under conditions where Gcd14p was tightly associated with Gcd10p (Fig. 5A), interaction between elF3 and Gcd10p may be highly sensitive to differences in strain background, extract preparation, or purification scheme.

The gcd10-504 and gcd10 $\Delta$ mutations had little or no effect on the levels of mature forms of several tRNAs, including elongator tRNA ${ }^{M e t}, \operatorname{tRNA}{ }^{\mathrm{His}}, \operatorname{tRNA}_{U A U}{ }^{\text {lle, }}$, and tRN A ${ }_{C G A}$ ser. Elongator tRN $A^{M \text { et }}$ contains $m^{1} A 58$, whereas tRN $A^{\text {His }}$ does not, and the sequences of the other two tRNAs are unknown (Sprinzl et al. 1998). It will be interesting to determine whether expression of any other tRNAs containing $\mathrm{m}^{1} \mathrm{~A} 58$ is impaired by gcd10 or gcd14 mutations. Given that the gcd10 $\Delta$ mutant was rescued by overexpression of initiator tRN A ${ }^{\text {Met }}$, 
it is likely that Gcd10p and Gcd14p play an essential role in maturation and accumulation of only this tRN A. Accordingly, it is conceivable that these proteins provide a novel means of regulating translation initiation, whereby modulating the maturation and stability of pretRNA ${ }_{i}{ }^{\text {Met }}$ in the nucleus would affect the formation of ternary complexes in the cytoplasm.

\section{Materials and methods}

Plasmid and yeast strain constructions

Table 1 contains the genotypes of all yeast strains used in this work. Details of plasmid constructions will be provided on request. Yeast strains YJA142, YJA143, and YJA146 were constructed by introducing plasmid p2705 (GCD10-HA) into strain BJ5464 (gift of E. Jones, Carnegie M ell on U niversity, Pittsburgh, PA) and then deleting chromosomal GCD10 by transformation to $\mathrm{Ura}^{+}$with a $6.6-\mathrm{kb}$ Xbal-Xhol fragment containing the gcd104::hisG::URA3::hisG allele (Alani et al. 1987) from pLPY 1. A U ra- gcd10 $4:$ hisG derivative (YJA 142) was selected by growth on SC medium containing $1 \mu \mathrm{g} / \mathrm{ml} 5$-FOA (SC +FOA). YJA143 was constructed by replacing plasmid p2705 in YJA142 with plasmid p2704 by plasmid shuffling (Boeke et al. 1987). Strain YJA 146 was constructed from YJA 143 as described in the Results section. To construct strains LPY 251 and LPY 252, a diploid from a cross between CH1305 and K2348 (a gift from K. Nasmyth, Research Institute of Molecular Pathology, Vienna, Austria) was transformed with the 6.6-kb gcd10s::hisG::URA3::hisG fragment from pLPY1, and the gcd10s::hisG::URA3::hisG allele was converted to gcd104::hisG as described above. One such U ra ${ }^{-}$strain, LPY 25, was transformed to U $\mathrm{ra}^{+}$with plasmid pLPY 5, bearing GCD 10 and U RA 3, sporulated and a U ra+ ascospore (LPY 251B) was isolated by tetrad analysis. After introduction of the LEU 2 plasmids pLPY 2 or pLPY 3 bearing GCD 10 or GCD 10-His, LPY 251B was cured of plasmid pLPY5 on 5-FOA medium to produce LPY 251 and LPY 252.

\section{High copy suppressor analysis}

Standard genetic techniques and culture media (SD, SC, and YPD) (Sherman et al. 1974) and the growth assays for sensitivity to 3-AT (Hinnebusch and Fink 1983) were described previously. Y east strains H2457 and HM 298 were transformed with a highcopy genomic library constructed in YEp24 (Carlson and Botstein 1982) and transformants were plated on minimal ly supplemented SD plates at $36^{\circ} \mathrm{C}$. Plasmids were isolated from $\mathrm{ts}^{+}$ transformants as described previously (Hoffman and Winston 1987) and shown to confer a ts ${ }^{+}$phenotype with reintroduction into $\mathrm{H} 2457$. The ends of the genomic inserts were sequenced using primers complementary to the sequences flanking the BamHI site in YEp24, and compared to the complete S. cerevisiae sequence (http://genome-www.Stanford.edu/Saccharomyces/) to identify the end points of the genomic inserts. Tn10 insertion libraries were constructed for each plasmid as described previously (Huisman et al. 1987). A Tn10 insertion that destroyed the suppressor function of plasmid p2634 was found to interrupt the IMT3 gene. On the basis that the other three IMT genes were present on the genomic inserts in suppressor plasmids p2632 (IMT1), p2633 (IMT2), and p2635 (IMT4), the IMT coding regions in all four plasmids were disrupted by inserting a 604-bp BssHII DNA fragment isolated from $\lambda$ phage DNA into a unique BssHII site present in each gene, generating

Table 1. Genotypes of yeast strains used in this study

\begin{tabular}{|c|c|c|c|}
\hline Strain & Genotype & $\begin{array}{c}\text { Plasmid } \\
\text { [name: rel evant gene] }\end{array}$ & Source or reference \\
\hline H2457 & $\begin{array}{l}\text { MAT } \alpha, \text { gcd10-504, gen2-101, his1-29, ura3-52, inol } \\
\text { (HIS4-lacZ, ura3-52) }\end{array}$ & & $\begin{array}{l}\text { M. Garcia-Barrio (NIH) and } \\
\text { M. Tamame }\end{array}$ \\
\hline H62 & $\begin{array}{l}\text { MAT } \alpha, \text { gcd10-503, his1-29, gen2-101, gen3-101, ura3-52, } \\
\text { (HIS4-lacZ, ura3-52) }\end{array}$ & & $\begin{array}{l}\text { Harashima and Hinnebusch } \\
\text { (1986) }\end{array}$ \\
\hline $\mathrm{Hm} 298$ & $\begin{array}{l}\text { MATa, gcd10-505, gcn2-101, his1-29, ura3-52, inol } \\
\text { (HIS4-lacZ, ura3-52) }\end{array}$ & & Garcia-Barrio et al. (1995) \\
\hline BJ5464 & $\begin{array}{l}\text { MAT } \alpha, \text { ura3-52, trp1, leu2 } 2 \Delta 1 \text {, his3 } \Delta 200, \text { pep:: HIS4, } \\
\text { prb1 } \Delta \mathrm{I}^{\prime} 1.6, \text { can1 Gal }{ }^{+}\end{array}$ & & E. Jones \\
\hline YJA142 & $\begin{array}{l}\text { MAT } \alpha, \operatorname{gcd} 10 \Delta:: \text { hisG, ura3-52, trp1, leu2 } \Delta 1 \text {, his3 } \Delta 200 \text {, } \\
\text { pep::HIS4, prb1 } 1 \Delta \mathrm{I}^{\prime} 1.6, \text { can1 Gal }^{+}\end{array}$ & [p2705:GCD10HA] & this work \\
\hline YJA143 & $\begin{array}{l}\text { MAT } \alpha, \operatorname{gcd} 10 \Delta:: \text { hisG, ura3-52, trp1, leu2 } 2 \Delta 1 \text {, his } 3 \Delta 200 \text {, } \\
\text { pep:: HIS4, prb1 } 1 \mathrm{I}^{\prime} 1.6, \text { can1 } \mathrm{Gal}^{+}\end{array}$ & [p2704:GCD10] & this work \\
\hline YJA146 & $\begin{array}{l}\text { MAT } \alpha, \operatorname{gcd} 10 \Delta:: \text { hisG, ura3-52, trp1, leu2 } 21 \text {, his } 3 \Delta 200 \text {, } \\
\text { pep:: HIS4, prb1 } 1 \text { I' }^{\prime} 1.6, \text { can1 Gal }{ }^{+}\end{array}$ & [p1775:IMT4] & this work \\
\hline $\mathrm{Hm} 296$ & $\begin{array}{l}\text { MAT } \alpha \text {, gcd14-2, his1-29, gen2-101, gen3-101, ura3-52, inol } \\
\text { (HIS4-lacZ, ura3-52) }\end{array}$ & & Cuesta et al. (1998) \\
\hline H1676 & MATa, prt1-1, leu2-3; leu2-112, ura3-52 & & $\begin{array}{l}\text { M. Ramirez (NIH) and A.G. } \\
\text { Hinnebusch }\end{array}$ \\
\hline TD-304-10 & MATa, leu2-3,-112, ura3-52, his4-303(ATT), sui2-1 & & $\begin{array}{l}\text { T. Donahue (Indiana } \\
\text { University, Bloomington) }\end{array}$ \\
\hline H56 & $\begin{array}{l}\text { MAT } \alpha \text {, gcd1-501, his 1-29, ura3-52, gen2-101, gen3-101, } \\
\text { (HIS4-lacZ, ura3-52) }\end{array}$ & & $\begin{array}{l}\text { Harashima and Hinnebusch } \\
\text { (1986) }\end{array}$ \\
\hline KAY 8 & $\begin{array}{l}\text { MAT } \alpha \text {, tif34 } 1 \text { 1, his1-29, gen2-508, ura3-52, leu2-3,-112, } \\
\text { (HIS4-lacZ, ura3-52) }\end{array}$ & [YCpLTIF34HA] & Asano et al. (1998) \\
\hline $\mathrm{CH} 1305$ & MATa, ade3, leu2, ura3, Iys2, can1, Gal ${ }^{+}$ & & C. Holm (UCSD) \\
\hline K2348 & $\begin{array}{l}\text { MAT } \alpha \text {, ade2-1, ade3, trp1-1, can1-100, leu2-3, his3-11,15, } \\
\text { ura3, } \mathrm{Gal}^{+} \mathrm{psi}^{+}\end{array}$ & & K. N asmyth \\
\hline
\end{tabular}


plasmids pJA104 (IMT2), pJA105 (IMT3), pJA106 (IMT4), and pJA 107 (IMT1). N one of the plasmids containing the disrupted IMT genes had suppressor activity in H2457, identifying the IMT genes as the dosage suppressors in plasmids p2623-p2625. A Tn10 insertion that destroyed the suppressor function of p2636 interrupted the LHP1 open reading frame. Plasmid p2626 (LHP1) was created by inserting a 1.7-kb Sall-Pvull fragment containing LHP1 into YEp24 digested with Sall and Smal. p2626 showed suppressor activity similar to that of p2636, proving that LHP1 is the suppressor gene in p2636. The high-copy plasmids pC 44 or p2626, bearing IMT4 or LHP1, respectively, were tested for the ability to suppress the ts ${ }^{-}$phenotypes of strains H 1676 (prt1-1), H56 (gcd1-501), and TD 304-10B (sui2-1) in comparison to the low-copy plasmids p2625, p256 (Hill and Struhl 1988), or p1234 (Vazquez de Aldana et al. 1993) bearing wildtype copies of PRT1, GCD1, or SU I2, respectively.

\section{Analysis of tRNA modification}

Total RNA was extracted from 300 grams (wet weight) of yeast cells grown in YPD medium (Rubin 1975) and tRN A was purified by DEAE-cellulose chromatography and deacylated (Hatfield et al. 1979), all as previously described. Transfer RNAs were aminoacylated with $\left[{ }^{3} \mathrm{H}\right]$ methionine $(70 \mathrm{Ci} / \mathrm{mmole}$, Amersham) or [ $\left.{ }^{35} \mathrm{~S}\right]$ methionine $(1000 \mathrm{Ci} / \mathrm{mmole}$; A mersham) under conditions of limiting tRN A and the labeled tRN As were fractionated by reversed-phase chromatography on a RPC -5 column (Kelmers and Heatherly 1971) essentially as described (Hatfield et al. 1979), except that el ution of aminoacyl-tRN As was carried out using a linear gradient of $0.45-0.65 \mathrm{M} \mathrm{NaCl}$ in the presence of $10 \mathrm{~mm}$ magnesium acetate. For HPLC analysis of base modifications, the tRN A was digested to nucleosides by nuclease P1 and alkal ine phosphatase (Gehrke et al . 1982) and the hydrolyzate was analyzed by HPLC according to the method of Gehrke and Kuo (1990).

\section{Acknowledgments}

We thank Christopher Yoo and Sandra Wolin for instruction and advice on in vitro transcription of tRN A genes, Dolph Hatfield for his assistance and advice on the analysis of tRN A modification by RPC -5 chromatography, and Kerstin Jacobsson for HPLC analysis of modified nucleosides. We thank Bobbie Felix for help in preparation of the manuscript. G.R.B. was supported by Grants from the Swedish Cancer Society (project 680) and Swedish N atural Science Research Council (BU-2930).

The publication costs of this article were defrayed in part by payment of page charges. This article must therefore be hereby marked 'advertisement' in accordance with 18 USC section 1734 solely to indicate this fact.

\section{References}

Alani, E., L. Cao, and N. Kleckner. 1987. A method for gene disruption that al lows repeated use of U RA 3 sel ection in the construction of multiply disrupted yeast strains. Genetics 116: $541-545$.

Anderson, J.T., M.R. Paddy, and M.S. Swanson. 1993. PUB1 is a major nuclear and cytoplasmic polyadenylated RN A-binding protein in Saccharomyces cerevisiae. Mol. Cell. Biol. 13: 6102-6113.

Asano, K., L. Phan, J. Anderson, and A.G. Hinnebusch. 1998. Complex formation by all five homologues of mammalian translation initiation factor 3 subunits from yeast Saccharo- myces cerevisiae. J. Biol. Chem. 273: 18573-18585.

Basavappa, R. and P.B. Sigler. 1991. The $3 \AA$ crystal structure of yeast initiator tRNA: Functional implications in initiator/ elongator discrimination. EMBO J. 10: 3105-3111.

Boeke, J.D., J. Trueheart, G. N atsoulis, and G.R. Fink. 1987. 5-Fluoroorotic acid as a selective agent in yeast molecular genes. Methods Enzymol. 154: 164-175.

Byström, A.S. and G.R. Fink. 1989. A functional analysis of the repeated methionine initiator tRNA genes (IMT) in yeast. Mol. Gen. Genet. 216: 276-286.

Carlson, M. and D. Botstein. 1982. Two differentially regulated mRN As with different $5^{\prime}$ ends encode secreted and intracelIular forms of yeast invertase. Cell 28: 145-154.

Cigan, A.M. and T.F. Donahue. 1986. The methionine initiator tRN A genes of yeast. Gene 41: 343-348.

Cigan, A.M., L. Feng, and T.F. Donahue. 1988. tRN $A_{i}{ }^{\text {Met }}$ functions in directing the scanning ribosome to the start site of translation. Science 242: 93-97.

Clark, M.W. and J. A belson. 1987. The subnuclear localization of tRN A ligase in yeast. J. Cell Biol. 105: 1515-1526.

Cuesta, R., A.G. Hinnebusch, and M. Tamame. 1998. Identification of GCD 14 and GCD 15, novel genes required for translational repression of GCN 4 mRN A in Saccharomyces cerevisiae. Genetics 148: 1007-1020.

Dever, T.E., W. Yang, S. Åström, A.S. Byström, and A.G. Hinnebusch. 1995. Modulation of tRN $A_{i}{ }^{\text {Met }}$, elF-2 and elF-2B expression shows that GCN4 translation is inversely coupled to the level of elF-2 - GTP . M et-tRN $A_{i}{ }^{\text {Met }}$ ternary complexes. Mol. Cell. Biol. 15: 6351-6363.

Diamond, A.M., I.S. Choi, P.F. Crain, T. Hashizume, S.C. Pomerantz, R. Cruz, C.J. Steer, K.E. Hill, R.F. Burk, J.A. McCloskey, and D.L. Hatfield. 1993. Dietary selenium affects methylation of the wobble nucl eoside in the anticodon of selenocysteine tRN A [ ${ }^{\text {Ser }}{ }^{S e c *}$. J. Biol. Chem. 268: 1421514223.

Feinberg, B., C.S. M CLaughlin, and K. Moldave. 1982. Analysis of temperature-sensitive mutant ts187 of Saccharomyces cerevisiae altered in a component required for the initiation of protein synthesis. J. Biol. Chem. 257: 10846-10851.

Garcia-Barrio, M.T., T. N aranda, R. Cuesta, A.G. Hinnebusch, J.W.B. Hershey, and M. Tamame. 1995. GCD10, a translational repressor of GCN4, is the RNA-binding subunit of eukaryotic translation initiation factor-3. Genes \& Dev. 9: 1781-1796.

Gehrke, C.W. and K.C. Kuo. 1990. Ribonucleoside analysis by reversed-phase high-performance liquid chromatography. In Chromatography and modification of nucleosides (ed. C.W. Gehrke and K.C. Kuo), pp. A3-A71. Elsevier, Amsterdam, The $\mathrm{N}$ etherlands.

Gehrke, C.W., K.C. Kuo, R.A. McCune, K.O. Gerhardt, and P.F. Agris. 1982. Quantitative enzymatic hydrolysis of tRNA: Reversed-phase high-performance liquid chromatography of tRN A nucleoside. J. Chromatography 230: 297-308.

Harashima, S. and A.G. Hinnebusch. 1986. Multiple GCD genes required for repression of $\mathrm{GCN} 4$, a transcriptional activator of amino acid biosynthetic genes in Saccharomyces cerevisiae. Mol. Cell. Biol. 6: 3990-3998.

Hatfield, D., C.R. Matthews, and M. Rice. 1979. Aminoacyltransfer RNA populations in mammalian cells chromatographic profiles and patterns of codon recognition. Biochim. Biophys. Acta 564: 414-423.

Hershey, J.W.B. 1991. Translational control in mammalian cells. Annu. Rev. Biochem. 60: 717-755.

Hill, D.E. and K. Struhl. 1988. Molecular characterization of GCD1, a yeast gene required for general control of amino acid biosynthesis and cell-cycle initiation. Nucleic Acids 
Res. 16: 9253-9265.

Hinnebusch, A.G. 1996. Translational control of GCN4: Genespecific regulation by phosphorylation of elF2. In Translational control (ed. J.W.B. Hershey, M.B. Mathews, and N. Sonenberg), pp. 199-244. Cold Spring Harbor Laboratory Press, Cold Spring Harbor, NY.

Hinnebusch, A.G. and G.R. Fink. 1983. Positive regulation in the general amino acid control of Saccharomyces cerevisiae. Proc. Natl. Acad. Sci. 80: 5374-5378.

Hoffman, C.S. and F. Winston. 1987. A ten-minute DN A preparation from yeast efficiently releases autonomous plasmids for transformation of Escherichia coli. Gene 57: 267-272.

Hopper, A.K. and N.C. Martin. 1992. Processing of yeast cytoplasmic and mitochondrial precursor tRN As. In The molecuIar and cellular biology of the yeast Saccharomyces (ed. E.W. Jones, J.R. Pringle, and J.R. Broach), pp. 99-141. Cold Spring Harbor Laboratory Press, Cold Spring Harbor, NY.

Huisman, O., W. Raymond, K.U. Froehlich, P. Errada, N. Kleckner, D. Botstein, and M.A. Hoyt. 1987. A Tn10-lacZ-kanRU RA 3 gene fusion transposon for insertion mutagenesis and fusion analysis of yeast and bacterial genes. Genetics 116: 191-199.

Jimenez, A., D.J. Tipper, and J. Davies. 1973. M ode of action of thiolutin, an inhibitor of macromolecular synthesis in Saccharomyces cerevisiae. Antimicrob. Agents Chemother. 3: 729-738.

Kagan, R.M. and S. Clarke. 1994. Widespread occurrence of three sequence motifs in diverse S-adenosylmethionine-dependent methyltransferases suggests a common structure for these enzymes. Arch. Biochem. Biophys. 310: 417-427.

Kelmers, A.D. and D.E. Heatherly. 1971. Columns for rapid chromatographic separation of small amounts of tracer-labeled transfer ribonucleic acids. Anal. Biochem. 44: 486495.

Kohrer, K. and H. Domdey. 1991. Preparation of high molecular weight RNA. In Methods in enzymology: Guide to yeast genetics and molecular biology (ed. C. Guthrie and G.R. Fink), pp. 398-405. Academic Press, San Diego, CA.

N aranda, T., M. Kainuma, S.E. McMillan, and J.W.B. Hershey. 1997. The 39-kilodalton subunit of eukaryotic translation initiation factor 3 is essential for the complex's integrity and for cell viability in Saccharomyces cerevisiae. Mol. Cell. Biol. 17: 145-153.

N aranda, T., S.E. M acM illan, and J.W.B. Hershey. 1994. Purified yeast translational initiation factor elF-3 is an RNA-binding protein complex that contains the PRT1 protein. J. Biol. Chem. 269: 32286-32292.

O'Connor, J.P. and C.L. Peebles. 1991. In vivo pre-tRNA processing in Saccharomyces cerevisiae. Mol. Cell. Biol. 11: 425-439.

Peterson, D.T., W.C. Merrick, and B. Safer. 1979. Binding and release of radiolabeled eukaroytic initiation factors 2 and 3 during $80 \mathrm{~S}$ initiation complex formation. J. Biol. Chem. 254: 2509-2519.

Phan, L., X. Zhang, K. Asano, J. A nderson, H.P. Vornlocher, J.R. Greenberg, J. Qin, and A.G. Hinnebusch. 1998. Identification of a translation initiation factor 3 (elF3) core complex, conserved in yeast and mammals, that interacts with elF5. Mol. Cell. Biol. 18: 4935-4946.

Rose, A.M., H.G. Belford, W.C. Shen, C.L. Greer, A.K. Hopper, and N.C. Martin. 1995. Location of $\mathrm{N}^{2}, \mathrm{~N}^{2}$-dimethylguanosine-specific tRN A methyltransferase. Biochemie 77: 45-53.

Rubin, G.M. 1975. Preparation of RNA and ribosomes from yeast. Methods Cell Biol. 12: 45-64.

Sherman, F., G.R. Fink, and C.W. Lawrence. 1974. Methods of yeast genetics. Cold Spring Harbor Laboratory, Cold Spring
Harbor, NY.

Simos, G., H. Tekotte, H. Grosjean, A. Segref, K. Sharma, D. Tollervey, and E.C. Hurt. 1996. Nuclear pore proteins involved in the biogenesis of functional tRNA. EMBO J. 15: $2270-2284$.

Sprinzl, M., C. Horn, M. Brown, A. loudovitch, and S. Steinberg. 1998. Compilation of tRNA sequences and sequenes of tRN A genes. Nucleic Acids Res. 26: 148-153.

Vazquez de Aldana, C.R., T.E. Dever, and A.G. Hinnebusch. 1993. Mutations in the $\alpha$ subunit of eukaryotic translation initiation factor 2 (elF-2 $\alpha$ ) that overcome the inhibitory effects of elF-2 $\alpha$ phosphorylation on translation initiation. Proc. Natl. Acad. Sci. 90: 7215-7219.

Wilson, S.M., K.V. Datar, M.R. Paddy, J.R. Swedlow, and M.S. Swanson. 1994. Characterization of nuclear polyadenylated RN A-binding proteins in Saccharomyces cerevisiae. J. Cell Biol. 127: 1173-1184.

Yoo, C.J. and S.L. Wolin. 1994. La proteins from Drosophila mel anogaster and Saccharomyces cerevisiae: A yeast homolog of the La autoantigen is dispensable for growth. Mol. Cell. Biol. 14: 5412-5424.

- - 1997. The yeast La protein is required for the $3^{\prime}$ endonucleolytic cleavage that matures tRNA precursors. Cell 89: 393-402. 


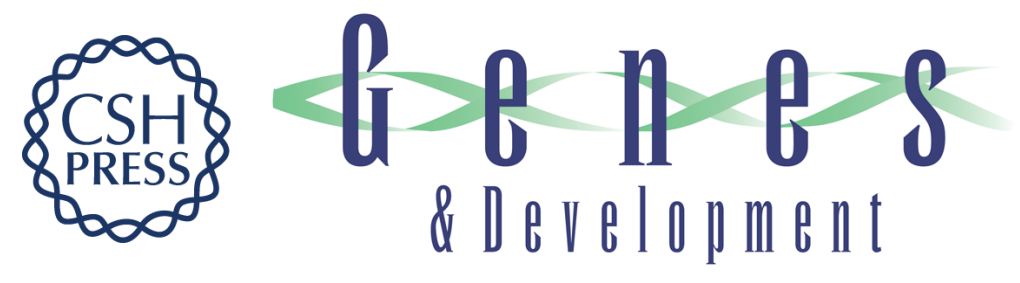

\section{The essential Gcd10p-Gcd14p nuclear complex is required for 1-methyladenosine modification and maturation of initiator methionyl-tRNA}

James Anderson, Lon Phan, Rafael Cuesta, et al.

Genes Dev. 1998, 12:

Access the most recent version at doi:10.1101/gad.12.23.3650

$\begin{array}{ll}\text { References } & \begin{array}{l}\text { This article cites } 39 \text { articles, } 22 \text { of which can be accessed free at: } \\ \text { http://genesdev.cshlp.org/content/12/23/3650.full.html\#ref-list-1 }\end{array}\end{array}$

License

Email Alerting Receive free email alerts when new articles cite this article - sign up in the box at the top Service right corner of the article or click here.

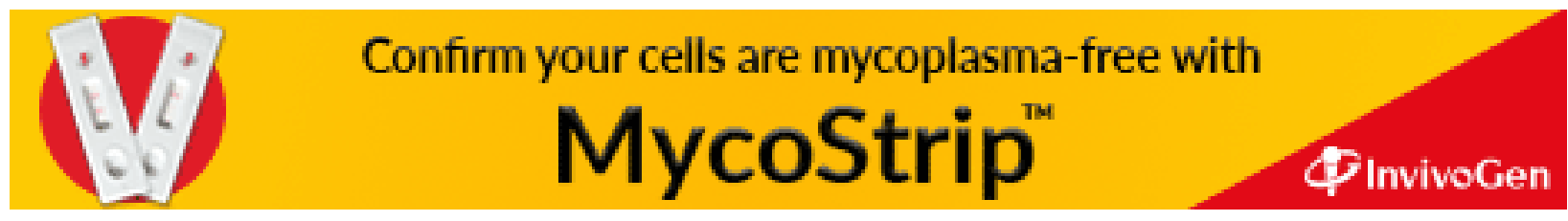

